Portland State University

PDXScholar

Fall 11-7-2012

\title{
The Crisis of Cooperation: A Critical Analysis of Russian-Iranian Relations in the Post-Soviet Era
}

Eric D. Moore

Portland State University

Follow this and additional works at: https://pdxscholar.library.pdx.edu/open_access_etds

Part of the Soviet and Post-Soviet Studies Commons

Let us know how access to this document benefits you.

\section{Recommended Citation}

Moore, Eric D., "The Crisis of Cooperation: A Critical Analysis of Russian-Iranian Relations in the PostSoviet Era" (2012). Dissertations and Theses. Paper 902.

https://doi.org/10.15760/etd.902

This Thesis is brought to you for free and open access. It has been accepted for inclusion in Dissertations and Theses by an authorized administrator of PDXScholar. Please contact us if we can make this document more accessible: pdxscholar@pdx.edu. 
The Crisis of Cooperation:

A Critical Analysis of Russian-Iranian Relations in the Post-Soviet Era

by

Eric Daniel Moore

A thesis submitted in partial fulfillment of the requirements for the degree of

\author{
Master of Science \\ in \\ Political Science
}

Thesis Committee:

Bruce Gilley, Chair

Ronald L. Tammen

Birol Yesilada

Portland State University

2012 
(C) 2012 Eric Daniel Moore 


\begin{abstract}
In the study of contemporary politics few interstate relationships have proven more instrumental, controversial, and perplexing to global policy makers than that which has persisted between Moscow and Tehran since the collapse of the USSR. Despite the great importance of Russian-Iranian relations to questions of global and regional politics there has, to date, been very little in the way of critical scholarship performed on the subject. While a wide-array of accounts from subject analysts provide a wealth of data on contemporary and historical events which have presumably defined and conditioned bilateral relations, there has been relatively little effort to isolate, examine, test, and evaluate those conditions or variables that are deemed salient to cooperation. In light of these circumstances, this study seeks to initiate a tradition of scholarship on RussianIranian relations that appeals broadly to the use of a scientific methodology.

The first step of any scientific inquiry requires attention devoted expressly to the development of a dependent variable of bilateral political affinity. While it remains outside the scope of this present investigation to analyze the host of factors/conditions capable of influencing bilateral relations, the formalization of a variable which records changing political affinity is a necessary first step and one that will fill-in a significant gap within the existing literary tradition. Rather than simply dismissing the extant tradition of literature on Russian-Iranian relations, this study seeks to aggregate and transform the subject's many diverse narratives into a user-friendly, quantitative, political metric which can form the basis for future empirical inquiry. Thus this study introduces a
\end{abstract}


new approach to monitoring and measuring changes in Russian-Iranian cooperation known as General Political Affinity (GPA).

Represented on the basis of a 21-point scaled indicator of bilateral affinity, GPA succinctly defines cooperation between Moscow and Tehran as the summation of three underlying, persistent issue dimensions: the trade in conventional weapons; cooperation in Iranian nuclear development; and level of agreement on matters of Caspian Sea delimitation. In more generic terms, these three criteria seek to evaluate interstate cooperation, generically, as a product of: defense cooperation; state-sponsored development assistance; and territorial agreement. The unique approach to operationalizing political affinity presented in this study not only functionally improves our ability to explain and predict the course of Russian-Iranian relations, but also provides a new schematic for evaluating bilateral relations among all political dyads. 


\section{Table of Contents}

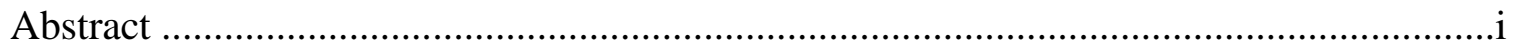

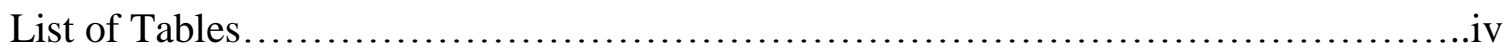

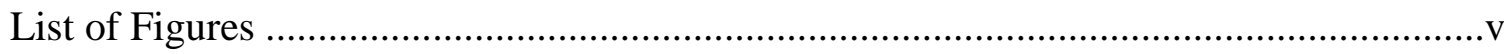

List of Acronyms....................................................... vi

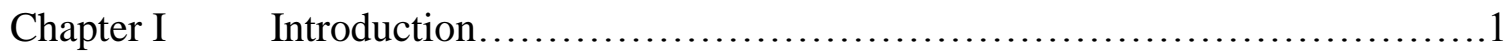

Chapter II Developments in Russian-Iranian Relations...........................7

Chapter III Measuring Bilateral Relations in the Post-Soviet Era: Constructing a composite dependent variable of General Political Affinity..............69

Chapter IV Conclusion.................................................98

References $\quad$.......................................................... 101

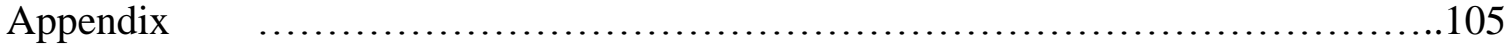




\section{List of Tables}

Table 1: $\quad$ 7-Point scale for sub-components of GPA......................... 71

Table 2: $\quad$ Coding scheme for transforming aggregate number of defense contracts (ANC) into 7point scale of cooperation................................73

Table 3: $\quad$ Coding scheme for nuclear cooperation event data.....................76

Table 4: $\quad$ Scaled Caspian Sea delimitation positions of the five littoral nations......80

Table 5: $\quad$ Coding scheme for Cooperation in Caspian Sea Delimitation based upon scaled position differences.......................................84

Table 6: $\quad$ Correlation matrix for analysis of GPA and Economic Utility for Partnership................................................90

Table 7: $\quad$ Correlation matrix for test of discriminant validity...................93

Table 8: $\quad$ Correlation matrix for test of convergent validity.....................95 


\section{List of Figures}

Figure 1: $\quad$ Bilateral exports between the USSR/Russian Federation and Iran...........................................................

Figure 2: $\quad$ Average number of arms-related contracts in successive 5-year periods

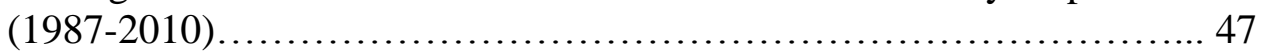

Figure 3: Annual Cooperation in the Trade of Conventional Weapons (1966-2010)

Figure 4: $\quad$ Annual Cooperation in Nuclear development (1966-2011)...............78

Figure 5: Annual Cooperation in Caspian Sea delimitation (1966-2010)...........84

Figure 6: $\quad$ Russian-Iranian General Political Affinity 1966-2011..................87 


\section{List of Acronyms}

$\begin{array}{ll}\text { ACND } & \text { Annual Cooperation in Nuclear Development (variable) } \\ \text { ACTW } & \text { Annual Cooperation in the Trade of Conventional Weapons (variable) } \\ \text { ANC } & \text { Aggregate Number of Contracts } \\ \text { ASM } & \text { Air to Surface Missile } \\ \text { BP } & \text { British Petroleum } \\ \text { CCSD } & \text { Cooperation in Caspian Sea Delimitation (variable) } \\ \text { CENTO } & \text { Central Treaty Organization } \\ \text { CRS } & \text { Congressional Research Service } \\ \text { E\&P } & \text { Exploration \& Production of hydrocarbon resources } \\ \text { ESD } & \text { Equal Share Division approach to Caspian Sea Delimitation } \\ \text { FSB } & \text { Russia's Federal Security Service } \\ \text { GDP } & \text { Gross Domestic Product } \\ \text { GPA } & \text { General Political Affinity } \\ \text { IAEA } & \text { International Atomic Energy Agency } \\ \text { IAEO } & \text { Iranian Atomic Energy Organization } \\ \text { IFOSA } & \text { Iran Foreign Oil Sanctions Act (1995) } \\ \text { IFV } & \text { Infantry Fighting Vehicle } \\ \text { IRI } & \text { Islamic Republic of Iran } \\ \text { ISSCEC } & \text { Iranian-Soviet Standing Commission for Economic Cooperation } \\ \text { MINATOM } & \text { Predecessor to Russia's present Ministry of Atomic Energy } \\ \text { MML } & \text { Modified Median Line approach to Caspian Sea Delimitation } \\ \text { MTCR } & \text { Missile Technology Control Regime } \\ \text { NATO } & \text { North Atlantic Treaty Organization } \\ \text { NIKIET } & \text { Scientific Research \& Design Institute for Energy Technologies (Russia) } \\ \text { SAM } & \text { Surface to Air Missile } \\ \text { SIPRI } & \text { Stockholm International Peace Research Institute } \\ \text { SOCAR } & \text { State Oil Company of the Azerbaijani Republic } \\ \text { SRAAM } & \text { Short-Range Anti-Aircraft Missile } \\ \text { SVR } & \text { Russian Foreign Intelligence Services } \\ \text { UGSS } & \text { Unified Gas Supply System of the Russian Federation } \\ \text { UNBISNET } & \text { United Nations Bibliographic Information System } \\ \text { UNSC } & \text { United Nations Security Council } \\ \text { USSR } & \text { Union of Soviet Socialist Republics } \\ & \end{array}$




\section{Chapter I \\ Introduction}

\section{Introduction}

In the study of contemporary politics few interstate relationships have proven more instrumental, controversial, and perplexing to global policy makers than that which has persisted between Moscow and Tehran since the collapse of the USSR. Alternating between periods of intimate cooperation and serious diplomatic fatigue, the status of Russian-Iranian relations at any given moment has captivated the attention of the world community because of its demonstrated importance to global affairs. Moscow's frequent diplomatic support of Tehran alongside of its recurrent transfers of conventional weaponry and nuclear technology have raised important concerns for regional and western leaders who fear that the Islamic Republic's coming of age will have unprecedented consequences for the status quo of relations in the middle east. Although Russian leaders have often sought to ease international concerns by making public promises to both restrict and/or monitor the scale of its cooperation with Iran, perhaps just as frequently the Kremlin has defaulted on these same commitments thereby causing western leaders to question Moscow's role in the global community. The duplicitous nature of Russia's policies towards Iran in the post-Cold War era have only further obscured the answer to whether or not Moscow is, today, a supporter of the global and regional status quo or whether it is, in fact, a dangerous revisionist power. 
Yet despite the great importance of Russian-Iranian relations to questions of global and regional politics there has, to date, been very little in the way of critical scholarship performed on the subject. While a wide-array of accounts from subject analysts provide a wealth of data on contemporary and historical events which have presumably defined and conditioned bilateral relations, there has been relatively little effort to critically isolate, examine, test, and evaluate those conditions or variables that are deemed salient to cooperation. If the question of Russian-Iranian relations is, in fact, critical to global governance, then the method of addressing this relationship must also be performed in a manner that is critical. In light of these circumstances, this study seeks to initiate a tradition of scholarship on Russian-Iranian relations that appeals broadly to the use of a scientific methodology.

The first step of any scientific inquiry will require attention devoted expressly to the development of a dependent variable of bilateral political affinity. While it will remain outside the scope of this present investigation to analyze the host of factors/conditions capable of influencing bilateral relations, the formalization of a variable which records changing political affinity is a necessary first step and one that will fill-in a significant gap within the existing literary tradition. Rather than simply dismissing the extant tradition of literature on Russian-Iranian relations, this study seeks to aggregate and transform the subject's many diverse narratives into a user-friendly political metric which can form the basis for future empirical inquiry. Thus this study 
introduces a new approach to monitoring and measuring changes in Russian-Iranian cooperation known as General Political Affinity (GPA).

Represented on the basis of a 21-point scaled indicator of bilateral affinity, GPA succinctly defines cooperation between Moscow and Tehran as the summation of three underlying, persistent issue dimensions: the trade in conventional weapons; cooperation in Iranian nuclear development; and level of agreement on matters of Caspian Sea delimitation. In more generic terms, these three criteria seek to evaluate interstate cooperation, generically, as a product of: defense cooperation; state-sponsored development assistance; and territorial agreement. The unique approach to operationalizing political affinity presented in this study not only functionally improves our ability to explain and predict the course of Russian-Iranian relations, but also provides a new schematic for evaluating bilateral relations among all political dyads.

By redirecting the analysis of Russian-Iranian relations into the realm of science, not only do we improve our ability to both explain and predict the course of relations between these two important nations, but so too do we begin to initiate a professional and more dynamic discussion. While the narrative efforts of so many analysts are indeed informative, without a carefully defined forum, much valuable information may easily become lost through a series of otherwise disparate monologues. In contrast, this study intends to create those conditions favorable to stimulating a rigorous dialogue surrounding one of the most important political relationships of the $21^{\text {st }}$ century. 


\section{$\underline{\text { Progress of Study }}$}

No critical evaluation of Russian-Iranian relations can proceed without first undertaking the necessary steps to creating a dependent variable of political affinity that efficiently depicts the changing nature of cooperation during the period in question. Despite the fact that there is much significant scholarship on the history of RussianIranian relations - the most significant of which is John W. Parker's (2008) incredibly rich account Persian Dreams - to my knowledge no one (including Parker) has thus far attempted to create a quantifiable index of bilateral relations in the post-Soviet era. Thus this study will be wholly dedicated to the process of constructing what I hereafter refer to as a dependent variable of General Political Affinity or GPA.

Beginning in Chapter II, I provide a comprehensive investigation of RussianIranian bilateral relations between the years of 1987 and 2011. While the scope of this study will focus predominantly upon the post-Soviet period, this chapter provides additional historical information at the outset that is both relevant to my study and which is also useful to the reader that is otherwise unfamiliar with general developments in Soviet-Iranian relations prior to the late 1980s. Beginning with the year 1987 I proceed to evaluate bilateral relations in discrete, five-year periods, narrowing the study's focus down to three substantive issue areas upon which I base my index of General Political Affinity, these areas are: the ongoing trade in conventional weapons; bilateral cooperation in nuclear development; and the status of agreement between both nations 
over issues of Caspian Sea delimitation. In each succeeding five-year period, I highlight the status of developments in each of these three areas.

While political cooperation may be gauged by any number of issues, the tradition of literature surveyed during this study suggests that these issue areas form a reliable core of political relations in the late-Soviet and post-Soviet periods. By training this chapter's focus upon three discrete areas of cooperation, I provide the amorphous concept of political affinity with a defined structure which allows the reader to gauge the changing scale of cooperation in a simplified and efficient manner.

Building upon the qualitative description of bilateral relations recounted in Chapter II, Chapter III consists of the formal development of a quantitative indicator of General Political Affinity. Taking the reader step-by-step through the formulation of each of the three subcomponents of GPA (trade in conventional weapons, cooperation in nuclear development, status of agreement on Caspian Sea delimitation), as well as the construction of the scaled, composite 21-point indicator itself, this chapter presents a model of Russian-Iranian cooperation that is intuitive, dynamic, unprecedented, and which accurately represents the qualitative historical discussion presented in Chapter II. Complementing the construction of this variable is a regime of testing in the final sections of the chapter which attempts to confirm GPA's utility for measuring bilateral political affinity between Moscow and Tehran. 
In Chapter IV, I conclude this study by reviewing the set of findings that are pertinent to understanding Russian-Iranian relations, and close with a discussion of future prospects for the empirical analysis of Russian-Iranian relations. 


\section{Chapter II \\ Developments in Russian and Iranian Bilateral Relations}

\section{Introduction}

In this chapter, I review the history of Russian-Iranian relations in both the Soviet and post-Soviet era analyzing the relationship in discrete five-year blocks for the period 1987-2011. While this chapter seeks to provide the unfamiliar reader with a rich summary of bilateral historical relations, it simultaneously functions as a platform for the development of a composite, dependent variable of General Political Affinity (GPA) covering the post-Soviet era. As discussed previously, the composite variable of GPA measures distinctly political relations between both the Russian Federation and the Islamic Republic of Iran according to three substantive issue areas on a year-by-year basis. The three areas of focus are: 1) defense relations - emphasizing the annual trade in conventional weapons; 2) interstate development assistance-here treated as annual Russian assistance in Iranian nuclear development; and 3) territorial agreementspecifically referring to the annual status quo of agreement in post-Soviet delimitation of the Caspian Sea.

While political affinity among nations has often been measured along a wide variety of state-oriented dimensions including similarities of domestic political institutions (Werner, 2000), security alliance portfolios (Tammen et al., 2000), and foreign policy positions (Signorino \& Ritter, 1999), there has also been a tendency within the tradition to make use of economic data as a means of describing changes in the 
quality of interstate relations across time. Without directly contradicting the proposition that economic trends can elucidate meaningful information about bilateral or multilateral political affinities, this study does determine to evaluate the quality of Russian-Iranian relations on the basis of overtly political variables as a means of preserving the overall clarity of such a notion as 'political affinity.' Thus, this study agrees with Bruce Bueno de Mesquita, who has argued in The War Trap against the use of economic indicators to measure political affinity writing, "economic relations represent a mixture of governmental policy and the policies and interests of actors in the private sectors" (Bueno de Mesquita, 1981, p. 110).

In the particular case of Russian-Iranian relations, reliance upon purely economic data would tend to skew one's perspective towards increasing bilateral cooperation across

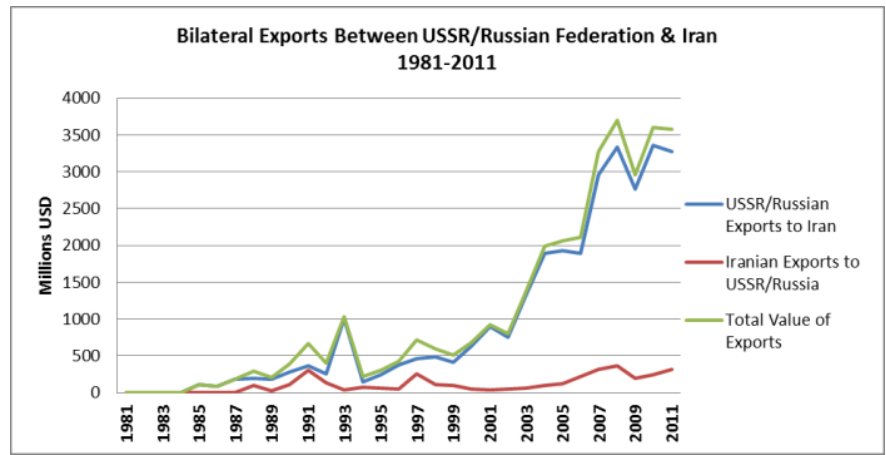

Figure 1: Bilateral Exports between the USSR/Russian Federation and Iran (1981-2011). Source: International Monetary Fund, "Direction of Trade Statistics" database. time failing, in the process, to acknowledge the significant diplomatic challenges faced by both nations throughout the entire post-Soviet era (see Figure 1). Creating a dependent variable which adequately hopes to measure bilateral political affinity, therefore requires a variable (or series of variables) which is capable of being highly sensitive to ongoing political debates, challenges, and opportunities - a condition which economic indicators are simply less likely to fulfill. 
This study will also try to limit its reliance upon more traditional, yet often generic, indicators of political affinity that focus narrowly upon a single issue-dimension of bilateral relations. As this chapter will demonstrate, although Russian-Iranian relations can be measured across a variety of planes, certain issue-dimensions have been of critical importance to both nations and, in fact, are unique to their bilateral relationship. While traditional indicators such as state security alliance portfolios or United Nations General Assembly (UNGA) voting are perhaps appropriate to large-scale studies involving numerous countries, such indicators fail to recognize the fact that each set of interstate relationships tends to hinge upon its own unique set of variables. Following the work of numerous scholars and analysts this study again suggests that Russian-Iranian interstate relations can best be understood by focusing attention upon three substantive issue areas: the sale of arms and military technology; cooperation in development of the Iranian civilian nuclear program; and the status of agreement or nonagreement on Caspian Sea delimitation. Although this chapter will explore a variety of factors comprising political cooperation, special attention will be paid in each sub-section to these three issues which, in turn, shall form the basis of a composite dependent variable of General Political Affinity. Chapter III will discuss the construction and formalization of that variable.

While this study will concentrate its focus upon the post-communist era (1992present), a cursory review of relations during the Soviet era (1917-1991) will prove itself invaluable to readers who are otherwise unfamiliar with the constantly shifting patterns of 
cooperation and non-cooperation that have come to define the long-term association of both capitals. It has become relatively commonplace among analysts to insist that relations between Moscow and Tehran have generally been troubled historically and that periods of improved affinity were likely due to changing geo-strategic conditions which merited some form of temporary cooperation (Parker, 2008, p. x-xi). Drawing upon a series of territorial and diplomatic disagreements dating back to the $19^{\text {th }}$ century, analysts frequently suggest that the resting state of relations between Moscow and Tehran is more often one of general non-cooperation fueled by many dour historical memories. Rather than qualifying the general state of relations between Moscow and Tehran as one defined by antagonism and non-cooperation, we might better understand the bilateral relationship as one of constantly changing conditions, where periods of cooperation and noncooperation are predictably and continually inter-woven into one another.

\section{Review of Relations during the Soviet Era (1917-1991): A geo-strategic alliance}

Although relations between the Russian and Persian empires had been strained by a series of treaties during the $19^{\text {th }}$ century that had formally transferred control of Persian territories in the North Caucasus to St. Petersburg (the 1813 Treaty of Gulistan \& the 1828 Treaty of Turkmanchai), at the outset of the $20^{\text {th }}$ century the status of relations was set to change (Parker, 2008, p. 1-2). The end to Tsarist rule in Russia and the rise of the communists to power in 1917 precipitated new opportunities for inter-governmental collaboration as the communist regime of the USSR sought to gain international political 
allies that could help to alleviate the potential threat of a British military intervention from the south as well as to deter British support for the anti-Bolshevik White army (Mamedova, 2009, p. 2-3; Rubinstein, 1982, p. 52). As part of an effort designed to protect the USSR from harmful implications of the Anglo-Persian Treaty of 1919, both parties signed the first Soviet-Iranian Treaty in 1921(Mamedova, p. 2-3; Rubinstein, p. 60-1). According to N.M. Mamedova, the 1921 Treaty operated as a generous political concession to the Persian monarchy. She indicates that under its terms the USSR not only agreed to release the Persian monarchy from all previous debts owed to Tsarist Russia, but also willfully divested itself of all Russian holdings in Iran including its claim to islands in the Caspian Sea while simultaneously preserving the Persian navy's right to operate in the Caspian (Mamedova, p. 2). Despite these impressive concessions, the USSR managed to preserve its own claim to territories in the North Caucasus as affirmed by the 1828 Treaty of Turkmanchai and gained important security assurances from Tehran (Parker, 2008, p. 2). Under the 1921 Treaty, article 5 ensured that neither nation could become a staging ground for hostile third-party operations against the other even going so far under article 6 as to provide the USSR with a legal right to enter Iran if the Persian regime was unable to guarantee compliance with article 5 (Mamedova, p. 3-4; Parker, p. 2-3; Milani, 2007, p. 329; Rubinstein, p. 61). Thus within four years of the October Revolution, relations between both capitals had turned a dramatic corner as the USSR and Persia sought to overcome resentments associated with the former Tsarist era. But a joint security commitment, debt forgiveness, and territorial agreement were not the 
only hallmarks of this new-found cooperation, between 1921 and 1933 both capitals would work together to forge a new, multi-faceted and highly productive economic relationship.

The interwar years can be described in largely cooperative terms. In Iran the regime of Reza Shah Pahlavi determined to make its newfound Soviet ally a critical partner in a broad new economic development agenda (Rubinstein, 1982, p. 61-2). Under this program both nations worked to create a variety of jointly managed enterprises designed to facilitate the bilateral trade in essential goods (Mamedova, 2009, p. 4-5). According to Mamedova during this period, the USSR became a primary export market for Iranian goods while simultaneously working to aid Iran in the development and regeneration of numerous export-oriented industries (p. 5). Citing a 1935 report by the People's Commissariat of Foreign Trade, Mamedova indicates that the USSR had "accounted for $35 \%$ of Iranian foreign trade...buying 100 percent of all Iranian exports of fish and ambary, 97.5 percent of rice and cattle, 90 percent of cotton, 86 percent of wool, 68 percent of silkworm cocoons, [and] 47 percent of leather and hides" (p. 6). Perhaps the most important product of these early joint efforts was the creation of Iran's first railway system which ran 900 miles and provided a critical linkage between both the Caspian Sea and Persian Gulf (Rubinstein, p. 62). Although Mamedova indicates that each nation's move towards increasing levels of dictatorship was placing real limits on trade growth, due to an overall downward pressure on the influx of private capital, it was not until the 
late 1930s that trade relations between both nations effectively collapsed (Mamedova, p. $6)$.

By Mamedova's account, the collapse in trade relations that would occur by the late 1930s was due to an emerging diplomatic row between Moscow and Tehran following the USSR's entrance into the League of Nations in 1934 (2009, p.6). Mamedova indicates that following the USSR's admission into the League, officials in Tehran began to request that Moscow abandon its rights under article 6 of the 1921 Treaty (the article providing the USSR with a right of occupation) arguing that security was effectively guaranteed to Moscow under the League of Nations charter, she writes:

However, the USSR refused to do so and this had an adverse effect on any further development of relations between the two countries...After the expiration of validity of the Treaty of 1935 [3 year validity], economic relations between the USSR and Iran practically ceased, as the Iranian side refused to prolong the treaty (Mamedova, p. 6).

During the years of World War II, Soviet-Iranian relations faced increasing challenges as leaders in Moscow became wary over Tehran's diplomatic overtures towards Germanyovertures made in spite of its otherwise stated position of neutrality (Rubinstein, 1982, p. 62). Having allowed German advisors into Iran, the USSR asserted that the Shah was unable to guarantee a commitment to Soviet security as outlined under articles 5 and 6 of the 1921 Treaty (Rubinstein, p. 62). On August 25, 1941 a combined Soviet and British force entered Iran with the British occupying the south and the Soviets occupying Iran's Northern provinces (Rubinstein, p. 62). Within six months Iran capitulated to the 
demands of the Soviets and British and formally entered into a tripartite alliance that would effectively transform Iran into a tactical and logistical partner to allied forces (Rubinstein, p. 62). The treaty, signed in January of 1942, not only secured Iran's allegiance to allied forces but also contained set guidelines for the withdrawal of foreign forces from Iran within six months of the conclusion of the conflict; while the British would honor their agreement by March of 1946, the Soviet decision to delay its withdrawal created more animosity between both capitals and left the Soviets firmly entrenched in Iran until May of 1946 (Rubinstein, p. 63-4). By some accounts the Soviet withdrawal could be credited to the influence of the United Nations Security Council which had begun to intervene at Iran's request in January of 1946, yet others suggest that the order to withdraw was given only after the USSR had achieved significant political concessions - one of which included the direct representation of the Soviet-backed Tudeh party in Prime Minister Qavam as-Saltaneh's cabinet (Rubinstein, p. 63-4).

Described as "the most powerful and best organized political party in Iran's modern history," (Milani, 2007, p. 329) Tudeh's direct ties to the USSR would be a constant source of concern for successive Iranian regimes throughout the Cold War era. A locally-rooted communist party, Tudeh, not only represented the interests of the USSR in the Iranian parliament and cabinet during the late 1940s, but it also became a vital platform for the USSR's increasing support to ethnic separatist movements then being organized in the northern provinces (including Iranian-Azerbaijan) (Rubinstein, 1982, p. 63-4). Iran's suppression of these autonomous movements under the Shah in the early 
1950s would become an increasing source of tension for both governments as the Shah's harsh public policy quickly swelled the number of immigrants to the USSR (Mamedova, 2009, p. 9). Perhaps most controversial of all, however, was Tudeh's close relationship to Prime Minister Mossadeq. This relationship had alarmed western nations to the growing power of Soviet influence in Iran and had apparently been the motive force behind the United States decision to support the Shah in Mossadeq's ouster in 1953 (Rubinstein, p. 65-6).

Immediately following the coup, the Shah worked quickly to eliminate Soviet influence in Iran by banning Tudeh's participation in government and strategically reorienting his nation towards the United States (Mamedova, 2009, p. 10; Milani, 2007, p. 329; Rubinstein, 1982, p. 66). Iran's subsequent decision to join the western-focused Baghdad Pact/Central Treaty Organization (CENTO) in 1955 as well as its formal rejection of articles 5 and 6 of the 1921 Soviet-Iranian — and the signing of a defense treaty with the United States just two days later in March of 1959-would effectively come to represent a complete breakdown in interstate political cooperation with the USSR (Rubinstein, p. 68). And yet, as is common to relations between Moscow and Tehran, a new era of renewed cooperation was predictably close at hand.

Between 1962 and 1963 Iran attempted to revitalize its diplomatic and economic relations with Moscow; Iran's efforts in these early years would lead to a renewed era of cooperation that would last for more than a decade, collapsing only after the infamous 1979 Iranian revolution (Rubinstein, 1982, p. 73). In 1962, the Shah made formal 
guarantees to Moscow that Iran would not house missile bases of any foreign nations on its soil, thereby demonstrating its new commitment to neutrality in the quickly polarizing world-system of the Cold War era (Rubinstein, 68-9). This initial move reignited relations and set off an important series of high profile diplomatic exchanges between 1962 and 1965 (Parker, 2008, p. 3-4; Mamedova, 2009, p. 9-10; Milani 2004, p. 329).

The Shah's increasing interest in developing cooperative relations with Moscow throughout the 1960s and 1970s is generally felt to be a reaction to the need for increasing diplomatic and economic support in Iran at a time when the Pahlavi regime's survival had been put at increasing risk due to a wave of unpopular economic and land reforms that had officially begun in 1963 - what is generally referred to as the "White Revolution;' by increasing ties to the USSR, the Shah believed he could both compensate for Washington's demonstrated failure to become a substantive partner in Iranian development and security while also staving off the likelihood of a Soviet-backed counter-insurgency aimed at suppressing his program of land reform (Parker, 2008, p. 5; Mamedova, 2009, p. 9; Rubinstein, 1982, p. 68, 73-4, 83). Rubinstein also indicates that rapprochement with the USSR was made feasible at this time due to a series of significant changes in U.S. policy within the region; specifically, he notes the fact that the United States was then making large-scale strategic upgrades to its nuclear arsenal in the region that would increase its deterrent capacity, while also simultaneously attempting to improve diplomatic ties with the USSR (despite the Cuban Missile Crisis of October 1962) (Rubinstein, p. 69). 
Between 1962 and 1974 Iran and the USSR would engage in a series of high-level diplomatic exchanges that produced many impressive results including: as much as $\$ 1$ billion in low-interest Soviet loans; a swap of Soviet military equipment for Iranian natural gas supplies; the introduction of new air-route agreements; long-term oil and gas contracts; the joint construction of the Trans-Iranian gas pipeline and negotiations for a second gas pipeline valued at $\$ 3$ billion; the creation of more than 100 various, long-term industrial development projects in such fields as metallurgy, oil and gas, petrochemicals, power development (including the development of uranium), agriculture, and the construction of related transportation infrastructure (Parker, 2008, p. 3-4; Mamedova, 2009, p. 9-10; Milani, 2007, p. 329; Rubinstein, 1982, p. 73, 76-7, 83-4). And while cooperation would continue generally through 1978, significant challenges to cooperation were increasing already by the mid-1970s.

One exception to this long-term expansion of cooperation was a notable dispute beginning in January 1974 over natural gas pricing in which Iran sought to increase the cost of gas exports to the USSR in accordance with the terms of a prior 1966 agreement that had indexed the price of natural gas exports to the value of crude oil on world markets (Rubinstein, 1982, p. 77-82). As oil prices rose in the wake of the Arab-Israeli War of 1973, tensions between Tehran and Moscow also increased as the Kremlin initially refused to accommodate Tehran's requests (Rubinstein, p. 77-82). Following the interruption of gas deliveries in July of that same year both nations quickly reached an accommodation that ended the crisis (Rubinstein, p. 77-82). Although overall 
cooperation between both nations was not truly hindered by these developments, they do provide a formal pretext for assessing both nations in the post-Soviet era as energy competitors. While present restrictions on Iran's development of natural gas supply capability limit the experience of direct competition today, this early event clearly demonstrates the potential for competition that is inherent in bilateral relations.

Other threats to sustained cooperation were also presented by increasing geopolitical rivalries between Iran and Iraq that were underwritten by an anticipated vacuum of power in the Gulf following the anticipated British withdrawal in 1971, Iranian military support for Kurdish movements in northern Iraq, and increasing military cooperation of Iraq and the USSR in response to the Kurdish autonomy movement (See Rubinstein, 1982, p. 83-9). While Rubinstein indicates that all of these factors definitely strained relations during the mid-1970s, he also notes that "none of the issues was acute enough to upset their détente" (p. 89).

Despite the otherwise substantive diplomatic and economic successes of these two decades, only the dramatic events of 1979 and the subsequent shift in Iranian domestic politics would ultimately lead to a serious rift in Iranian-Soviet relations (Milani, 2007, p. 330). Following the Shah's ouster and the subsequent return to Iran of the Ayatollah Khomeini in February 1979, the Ayatollah immediately declared a policy of nonalignment with either the East or West and began implementing a series of decisions which would decisively fracture relations with the USSR (Parker, 2008, p. 6; Mamedova, p. 11). No longer would Iran pursue a pragmatic policy of cooperation with Moscow 
focused upon economic development and security gains; the new Islamic regime would pursue an ideologically-driven foreign policy that chose to insulate Iran from the ongoing geo-political rivalries between the USSR and United States that had polarized the region. On May 11, 1979 Iran annulled articles 5 and 6 of the 1921 Soviet-Iranian treaty which effectively opened up Iranian territory to third-party powers hostile to the USSR (Parker, p. 8; Mamedova, p. 11). And while Khomeini's regime may have sought to distance itself from taking sides in the Cold War rivalry by pursuing a policy of genuine independence, ultimately it could not insulate itself from the impact of ongoing geopolitical rivalries between the USSR and the United States.

By all accounts the USSR's December $27^{\text {th }}, 1979$ invasion and subsequent occupation of Afghanistan dealt a dramatic blow to bilateral relations between Moscow and Tehran. According to multiple sources, the USSR's decision to invade had been premised upon the suspicion that following the removal of the Shah-a key ally to Washington - the United States would seek to entrench itself in neighboring Afghanistan as a means of maintaining regional influence and intelligence gathering capacity (Milani, 2007, p. 330). The forcefulness of Soviet policy no doubt disturbed the newly formed regime in Iran as it demonstrated a new side to Soviet policy within the region, one that now included direct military intervention. Overtime the ongoing conflict between the Soviets and U.S. and Iranian-backed counter-revolutionaries would send more than 2 million refugees into neighboring Iran thereby causing the Ayatollah's regime to bear the extensive socio-economic and political burden of instability (Milani, p. 330). The Soviet 
occupation of Afghanistan was quickly followed by multiple invasions of the Soviet embassy in Tehran and, as Parker notes, led Iran, just three later months, to once again discontinue its export of natural gas supplies to Soviet Republics in Central Asia while also directly curtailing its economic cooperation with the USSR (Parker, 2008, p.6, 12; see also Mamedova, 2009, p. 11).

The eruption of the Iran-Iraq war in 1980 only further worked to destroy ties between Moscow and Tehran as the Ayatollah's stated policy of independence from Cold War alliances deprived it of much needed military support in the face of a growing Western and Soviet-backed Iraq. Although Moscow's direct provision of weaponry to Iran largely ceased in 1978 (SIPRI, 2011, Arms Transfer Database), Parker indicates that Moscow would continue to provide Tehran with supplies through indirect channels, noting also that such 'indirect flows' were further 'restricted' in 1982 when Khomeini both rejected Saddam Hussein's calls to end ongoing hostilities while also calling for the removal of the Baathist regime (Parker, 2008, p. 13).

By Parker's account, the USSR had been concerned predominantly with maintaining the status quo of power relations in the Middle East and saw the ongoing conflict as likely to alter the existing balance of power by encouraging direct intervention by the United States (Parker, 2008, p. 13). The withering of Soviet military support preceded what Parker has referred to as the "low point" in bilateral relations that occurred in 1983 as the Khomeini regime arrested and executed 45 members of the Moscowbacked communist Tudeh party in Iran and required the USSR to recall a substantial 
number of its diplomats from its embassy in Tehran (Parker, p. 16-17; Mamedova, 2009, p. 11). Still, even in the midst of a radically diminished non-cooperation there are indications that this 'restricted' flow of weapons from the USSR to Iran continued throughout the life of the war. Citing a November 30, 1986 Sunday Times report, Reuters has reported that the USSR had continued to send indirect flows of weapons to Iran as part of a strategic imperative of building rapport with Iranian leaders that could be capitalized upon following the anticipated death of Ayatollah Khomeini (Reuters, 1986, November 30). According to these reports, the USSR secretly contributed weapons to the Iranian war effort via North Korea, Czechoslovakia, Libya, and Syria” (Reuters).

Thus by the mid-1980s, political relations between the two nations had been strongly undermined by ideological divisions and the polarizing effect of regional hostilities. But the substantial decline in bilateral cooperation, once again, could not be expected to last. According to Eva Patricia Rakel, years of international isolation, war fatigue, and economic malaise, by the late 1980s, would encourage the Iranian leadership to seek out cooperative engagement with regional powers as a means of restarting stalled national development (Rakel, 2007, p. 170).

\section{Relations in the Late-Soviet and Post-Soviet Era (1987-2011): Developing a dependent variable of political affinity}

1987-1991: New Beginnings in the Post-Communist Era Average GPA Score for Period: 13.6, High-Level of Moderate Cooperation 
By 1987 the USSR and Iran began to take the very first steps towards a general state of rapprochement, thereby ending nearly eight years of estrangement that had followed in the wake of the 1979 Iranian revolution and Soviet invasion of Afghanistan. Just one year prior in August of 1986, declining global oil prices had pushed Tehran to reopen its sale of gas supplies to the Soviets (valued then at \$2billion/year) as part of an effort to boost its economy (Hiro, 1986, December 21), and by December of that same year the Iranian-Soviet Standing Commission for Economic Cooperation (ISSCEC) met in Tehran for the first time since the disruption of its activities in 1980 (Parker, 2008, p. 21; Hiro). According to Dilip Hiro writing for the Los Angeles Times, "The list of industries included in [the ISSCEC] agreement was significant [and included]: transport, steel mills, machine tools, power plants, fishing, banking, construction, and technology" (Hiro). With the Iranian Foreign Minister Ali Akhbar Velayati visiting Moscow in February 1987 and the Soviet Deputy Foreign Minister Yuli Vorontsov visiting Tehran in August that same year, both nations concluded new agreements over the construction of power plants and refineries in Iran as well as the further development of related oil pipelines and railways (Parker, p. 21). All of this served as increasing pretext for the Ayatollah's January $1^{\text {st }}, 1989$ letter to Soviet General Secretary Mikheil Gorbachev which called for a return to cooperative engagement (Parker, p. 29; Mamedova, 2009, p. 12; Imam Khomeini official website).

Where Rakel has noted that Iran sought to reevaluate its relations with regional partners in accordance with the rise of pragmatists in the Iranian policy bureaucracy who 
saw enhanced foreign relations as a means to economic reconstruction and continuing political legitimacy (Rakel, 2007, p. 170), Parker and Mamedova indicate that the ceasefire signed between Iran and Iraq in August of 1988 and the likelihood of a forthcoming Soviet withdrawal from Afghanistan provided the necessary pretext for rapprochement (Parker, 2008, p. 29; Mamedova, 2009, p. 11). Parker determines that the normalization of relations between the USSR and Iran specifically hinged upon the Ayatollah Khomeini's letter to Soviet General Secretary, Mikheil Gorbachev, in January of 1989 which called for a return to cooperative engagement (Parker, p. 23, 29).

Following Khomeini's letter of proposed cooperation and the withdrawal of Soviet forces from Afghanistan the following month, both nations exchanged visits of foreign ministers between February and March thereby laying the groundwork for a proposed Iranian delegation to visit Moscow later that year in June (Parker, 2008, p. 29; Mamedova, 2009, p. 12). The June round of talks between high-ranking officials (including both General Secretary Gorbachev and Majlis Speaker Rafsanjani) would come to define a turning point in Soviet-Iranian relations as it committed both nations to cooperation across a wide range of issue areas through the year 2000 including: joint economic development projects; cooperation in matters of regional security; cooperation in the development of civilian nuclear energy programs; and a general agreement on the sale of arms (Parker, p. 31-2, 36; Mamedova, p. 12).

Whether or not the death of Iranian Supreme Leader Ayatollah Khomeini just three weeks prior to the delegation's visit contributed to the highly cooperative outcome 
is uncertain, but appears likely given the fact that his passing has been associated with an opening of policy space in Iran. According to Rakel, the death of Khomeini enabled pragmatist and conservative party factions to actualize their growing preference for a foreign policy based upon engagement rather than that of isolation and unilateralism (Rakel 2009, p. 105, 116-18). One of the leading proponents of a more liberal foreign policy was none other than the delegation's leader and known pragmatist, then Speaker of the Majlis, Hashemi Rafsanjani (Parker, 2008, p. 31). Within just two months of the Moscow talks Rafsanjani would be elected to a redesigned presidency that entrusted the executive with increasing control over foreign policy decision-making (Rakel 2007, p. 170). In the course of his presidency, Russian-Iranian relations would come to achieve unprecedented levels of commercial, technical, and diplomatic cooperation through the fulfillment of arms contracts and a program of nuclear development which had been agreed upon during the June, 1989 talks.

Between 1989 and 1991, the Russian Federation would sign and begin delivery on numerous contracts for a vast array of high-profile defense-related goods which signaled, definitively, the beginning of Soviet-Iranian rapprochement. While such weapons transfers clearly included weapons systems that could be employed in an offensive capacity (a fact that would become highly disturbing to Washington in the coming years), Moscow had defended its emerging weapons relationship as one that was inherently 'defensive' in nature (Parker, 2008, p. 32; Kempster, 1989, June 24). These contracts initially included the purchase and delivery of $24 \mathrm{Mig}-29$ and 12 Su24MK strike aircraft, 
an assortment of short-range anti-aircraft missiles (SRAAM) for fighter aircraft, surface to air missiles (SAM), air to surface missiles (ASM), bomber aircraft, and air search radar for use with missile systems, (SIPRI, 2011, Arms Transfer Database; Parker, p. 34). Perhaps the most controversial contracts, however, were those authorizing orders for the sale of 3 Kilo-class submarines which would be delivered to Iran between 1992 and 1993 (SIPRI). The USSR would also agree to the sale of tanks, infantry fighting vehicles (IFV) and anti-tank missiles in 1991—in long-term contracts which would be delivered on throughout the remainder of the decade (SIPRI); notably, however, the deliveries of these later goods would not begin until 1993, due perhaps to a decline in general cooperation during 1992 — which as will be discussed in the following section-was precipitated by the outbreak of the Tajik civil war.

It is tempting to ask whether or not the increasingly robust weapons relationship of the early 1990's was strategically important to leaders of the USSR who, at that time, were fighting a political battle against republican nationalists seeking to dissolve the longstanding USSR? Were such transfers signed in order to develop external support for the USSR at a time of increasing risk to state sovereignty? Although the question is difficult to answer, there is some indication that increasing political fragility of the USSR may have been part of the motives for expanding weapons-based cooperation in the late 1980s and early 1990s. In September 1991, just three months prior to the Soviet Union's dissolution, General Secretary Gorbachev dispatched a letter to president Rafsanjani reiterating the commitment of the each of the individual republics and Union as a whole 
to continued cooperation with the IRI (Parker, 2008, p. 37). In this context it is reasonable to suspect that a rapidly expanding weapons relationship was, in part, designed to generate increasing diplomatic favor with Union allies. And while the longstanding Union would cease to exist in December of 1991, the Russian nationalist administration of Boris Yeltsin would - throughout the remainder of the 1990s preside over a deepening bilateral relationship with the Islamic Republic of Iran (IRI).

But weapons-based cooperation was not the only hallmark of this period. Between 1987 and 1991 the Russian Republic and the Islamic Republic remained in continuous agreement over the issue of Caspian Sea delimitation, subscribing still to the 200 mile Astara-Gasanguly (Hasan-Qoli) median line of demarcation which had been informally agreed to in 1935 and was based upon existing Soviet-Iranian land borders (Parker, 2008, p. 151; Mamedova, 2009, p. 7). Although Parker notes that the collapse of the USSR in 1991 had re-opened up this informal regime to potential renegotiation, at least through 1992 both nations still continued to endorse the median-line divider as well as the existing 'condominium-approach' which provided both nations with equal rights in respect to navigation and resource utilization (Parker, p. 150-1). As will be demonstrated in the following section, the issue of Caspian Sea Delimitation would become increasingly controversial throughout the decade as newly independent Caspian littoral states began to stake claims to maritime resources in proximity to their coastline prior to any successful renegotiation of the Caspian Sea legal regime. 
In terms of bilateral cooperation in the field of nuclear development prior to the 1989 agreements, the USSR had neither formally nor informally engaged Iran on the topic — a sure sign of diminished bilateral affinity. While the June round of talks in 1989 did not produce specific contractual agreements between both parties to cooperate in the field of nuclear power they did, in fact, establish a formal expectation that both parties would work together in the future toward the "peaceful use of atomic energy" (Parker, 2008, p. 31; Mamedova, 2009, p. 12). According to Parker, Viktor Mikhaylov-former Russian Minister of Atomic Energy, would later report that the June 1989 agreements had been the foundation for Russia's later cooperation in the completion of Iran's Bushehr nuclear power plant (Parker, p. 111).

Thus the period of 1987 to 1991 can generally be treated as a period of initial rapprochement wherein both parties committed themselves to a profound reconceptualization of their mutual relationship, pursuing cooperation rather than competition.

1992-1996: Navigating the complexities of post-Soviet affairs-challenges and opportunities Average GPA Score for Period: 15.625, Low-Level of High Cooperation

The five year period between 1992 and 1996 represents one of the most interesting periods in Russian-Iranian relations since the general state of rapprochement that began in 1989. While the period, overall, is defined by a level of High Cooperation-due to the ongoing trade in defense-related goods and the initial 
commitment of the Russian government to begin completion of Iran's Bushehr nuclear power plant — collaboration was still being challenged by the breakup of the Soviet Union which had fractured the existing status quo of relations within Central Asia and the Caspian region. The opportunity for expanded relations with the United States, the outbreak of civil war in the former soviet republic of Tajikistan, and the re-evaluation of the long-standing Caspian Sea regime by newly-independent littoral states would come to place a substantial burden of pressure upon Russian-Iranian relations during this period thereby threatening the fragile rapprochement that had been brokered in 1989 .

Although the Russian republic emerged from the collapse of the USSR in full possession of the Soviet Union's former agreements with Iran, the direction of national policy appeared uncertain in the early years of independence as Russia sought both to maintain the status quo of relations with Iran while also exploring new relations with Washington. The absence of normal diplomatic relations between the U.S. and Iran was a significant hurdle to the newly independent Russian republic as it sought to develop bilateral relations with Iran based upon the USSR's 1989 agreements. Continuing to fulfill its controversial weapons contracts with Iran while also formalizing its commitment to bilateral cooperation in the field of nuclear technology, Russia's policy of engagement during this period became increasingly worrisome to officials in Washington who feared the growing consequences of proliferation in weapons and dual-use technology that could enable Iran to militarize its civilian nuclear program. 
In an effort to appease Washington during this era, Russian Foreign Minister Andrei Kozyrev in March 1993 visited Washington and proposed the establishment of a new non-proliferation forum - the Gore-Chernomyrdin Commission (Parker, 2008, p. 113). While this commission would become increasingly important to Russian-U.S. relations throughout the 1990s, the relationship would consistently be tested by the fact that Russian-Iranian cooperation in the sale and transfer of weapons and nuclear based technology continued to deepen as the decade progressed. Between 1992 and 1996 Moscow would negotiate new defense contracts with Iran for the provision of a Kiloclass submarine, diesel tank engines, as well as anti-tank missiles while also continuing to make good on its deliveries of defense contracts signed in 1991 (SIPRI, 2011, Arms Transfer Database).

In terms of bilateral nuclear cooperation, this period demonstrated the development of agreements associated with Russia's anticipated participation in the construction of Iran's Bushehr nuclear power plant - a facility that had been left uncompleted by the German firm Siemens in the wake of the 1979 revolution and IranIraq War (Orlov \& Vinnikov, 2005, p. 50; Wehling, 1999, p. 136). Early agreements were signed in August 1992 and according to Orlov and Vinnikov represented a significant future commitment on the part of Russia to nuclear development in Iran (Orlov \& Vinnikov, 50; Parker, 113). Describing these agreements Orlov and Vinnikov (2005) write: 
[N]uclear cooperation would consist of construction of nuclear power plants for Iran, cycling nuclear fuel, supplying research reactors, reprocessing spent fuel, producing isotopes for use in scientific research and medical research and training of Iranian nuclear scientists at the Moscow Engineering Physics Institute (p. 50). By January 1995 these agreements had led to a formal contract signing between

the Russian Ministry of Atomic Energy (MinAtom) and the Iranian Atomic Energy Organization (IAEO) for construction of the Bushehr 1 nuclear power plant at a cost to Iran of $\$ 800$ million USD (Orlov \& Vinnikov, p. 51; Parker, 2008, p. 114) with a formal construction agreement signed between IAEO and the Russian firm Zarubezhatomenergostroi (Orlov \& Vinnikov, p. 50-1).

Responding to international concerns that Russian collaboration in the field of nuclear science could enable Iran to produce nuclear weapons, Russia's Foreign Intelligence Services (SVR) issued successive reports in 1993 and 1995 arguing that bilateral cooperation was unlikely to enable Iran to produce a weapon (Orlov \& Vinnikov, 2005, p. 52; Parker, 2008, p. 115). And yet, while these reports vehemently defended Russia's cooperation as oriented solely toward the development of civilian nuclear technology, analysts indicate that one of Yeltsin's presidential advisory bodies, the Security Council, had discovered a series of secretive side deals between MinAtom Director Viktor Mikhaylov and the IAEO for the provision of 2000 tons of uranium, uranium mining assistance, and a gas centrifuge capable of enriching the uranium to "weapons-grade level," as well as the training of Iranian scientists in Russia (Parker, p. 116-7; Orlov \& Vinnikov, p. 52; Wehling, 1999, p. 136). Orlov and Vinnikov indicate that the Security Council report was made available to the Ministry of Foreign Affairs 
which, in turn, cancelled the protocol of intent with the IAEO by May of 1995 (Orlov \& Vinnikov, p. 52). Despite the fact that the Russian Foreign Ministry formally sought to suspended illicit nuclear cooperation with Iran, international officials clearly pressured the Yeltsin regime to more aggressively pursue a policy of non-proliferation; there can be little doubt that this added pressure did not negatively impact bilateral cooperation during this period.

Between May and August of 1995 the Russian Federation would not only agree (through the Gore-Chernomyrdin Commission) to ending all bilateral arms cooperation with Iran - following the completion of its existing contracts in 1999-but it also became a signatory to the Missile Technology Control Regime (MTCR) and a member of the Wassenar Arrangement which aimed to curb "destabilizing transfers of conventional arms and dual-use goods and technologies (Parker, 2008, p. 117; MTCR.org; Wassenar.org). Thus while bilateral cooperation would continue in the short term, it appeared that long-term cooperation with Iran was being sacrificed by the Kremlin as part of a strategy aimed at cultivating favor with the West in the early post-Cold War era. But emerging relations with Washington were not the only challenge to Russian-Iranian cooperation during this era, the break-up of the Soviet Union had led to a dramatic alteration in the regional status quo which placed new pressures of its own on the fragile relationship.

The collapse of the USSR in 1991 had opened up the likelihood that the longstanding Caspian Sea delimitation regime between the Soviet Union and Iran would need 
to be revised in accordance with the maritime borders of four new independent nations (Russia, Azerbaijan, Kazakhstan, and Turkmenistan) and Iran (MacDougall, 1997, p. 89; Parker, 2008, p. 151). While Russia and Iran continued to publicly endorse a common approach to Caspian Sea delimitation throughout this entire period (see Mahmoud Ghafouri, 2008), elites within the Russian Federation became increasingly divided over whether or not Moscow should continue to pursue a delimitation regime that was strategically favorable and promoted ongoing cooperation with Iran or one that maximized Russian economic opportunities at the cost of bilateral affinity (See Parker, p. $152-3)$.

Joint exploration and production opportunities (E\&P) in Azerbaijan had attracted Russian energy opportunists as early as 1993 thereby angering the Iranian leadership who argued that states could not engage in unilateral E\&P prior to the successful renegotiation of the existing regime (Parker, 2008, p. 152-3). By the close of this period, RussianIranian relations would become increasingly strained not only over the formalization of E\&P contracts between Russia and Western corporations in Azerbaijan's so-called 'national sector' but also over apparent Iranian reprisals which consisted of talks over rival pipeline cooperation with both Turkey and Turkmenistan between December 1994 and August 1995 which challenged Moscow's regional energy hegemony (Parker, p. 154; Olcott, 2004, p. 11-13; Kemp, 2000, p. 153). And while divisions between policy elites in Russia clearly contributed to growing bilateral tensions in this area, it is simultaneously 
the case that these same divisions likely functioned to stabilize cooperative relations by mitigating more negative outcomes.

Despite the fact that Russian President Boris Yeltsin and Prime Minister Viktor Chernomyrdin (then deputy premier in charge of the fuel and energy sector and Gazprom Chair) had officially supported Russia's participation in controversial Azerbaijani E\&P agreements - thereby suggesting a de facto policy reversal over issues of Caspian delimitation-Russia's Foreign Intelligence Services (SVR) under the Direction of Yevgeny Primakov and the Foreign Ministry publicly argued in favor of renegotiating the legal regime prior to commencement of E\&P by any one nation (Parker, 2008, p. 149, 152-3; MacDougall, 1997, p. 97-99). Thus while Russia's de facto policy reversal over Caspian delimitation associated with the position of Yeltsin and Chernomyrdin clearly functioned to strain relations with Iran, high-level opponents of this policy likely functioned - at minimum - to slow the growing rift between Russia and Iran over Caspian delimitation during this period.

As Mahmoud Ghafouri's research demonstrates, throughout this period both Russia and Iran continued to rhetorically endorse the same delimitation regime, with both nations arguing in favor of a condominium approach to resource utilization (Ghafouri, 2008); notably, in 1996 both nations (including also Turkmenistan) agreed to a change in the existing regime which supported the extension of an excepted 10 mile offshore zone to a 45 mile offshore zone (Ghafouri, 2008, p. 87-8). It seems more than likely that this mutual modification of the existing delimitation regime functioned to quell growing 
tensions between the two nations. Russia's willingness still to cooperate with Iran in these matters may have been urged by the SVR and Foreign Ministry as part of a tactical effort designed to encourage cooperation with the Islamic Republic at a time when Russia required increasingly affine relations in order to preserve regional security.

One of the leading challenges to Russian-Iranian relations during this era was the outbreak of civil war in the newly independent Republic of Tajikistan (Parker, 2008, p. 57; Power, 1993, August 6). Growing tensions between the ruling Tajik government of communist leader Rahmon Nabiyev and the domestic Islamic Revival Party during 1992 had attracted the diplomatic and tactical military support of the Iranian government, thereby stirring fears within Moscow over the role that Iran might choose to play within Russia's predominantly Muslim regions as well as in the greater post-Soviet sphere (Parker, p. 57, 71, 73, 74; Freedman, 1997, p. 105). Having experienced a large-scale revival of domestic Islamic political movements in the wake of the USSR, along with recent memories of fighting Islamist forces in Afghanistan during the 1980s, Moscow was by the early 1990s already highly sensitive to the potentially disruptive role Iran could play within the region (Trenin \& Malashenko, 2004, p. 12; Power, 1993). Parker has indicated that following Nabiyev's ouster by Islamic opposition forces in September 1992, Russia - principally through the Foreign Ministry and SVR (Parker, p. 86, 97)— became deeply involved in the brokering of peace and engaged Iran directly on the topic by tying the future of bilateral relations to the Islamic Republic's behavior in Tajikistan (Parker, p. 80, 86). 
With work on a new draft political treaty between the Russian Republic and Iran underway by October, and a recent August 1992 agreement signed on the construction of a nuclear power plant in Iran, Russian leaders successfully worked to change the course of Iranian behavior in Tajikistan (Parker, 2008, p. 86, 113). By Parker's account, Iranian support for opposition forces was effectively concluded by 1993 and was replaced by a new joint-effort of both Russian and Iranian leaders to broker negotiations between Tajik parties beginning in April 1994 (Parker, p. 81, 86). Although episodic conflict among Tajik opponents would continue throughout negotiations, Russian-Iranian diplomatic coordination on this matter has been widely recognized as contributing to the eventual peace agreement signed between Tajik disputants in Moscow during June of 1997 and represents a significant accomplishment in terms of bilateral cooperation (Parker, p. 176; Rakel, 2007, p. 171).

1997-2001: Cooperation under Pressure Average GPA Score for Period: 14.475, Low-Level of High Cooperation

Between 1997 and 2001, Russian-Iranian relations would face many of the same challenges that had evolved in the preceding era. Although hostilities in Tajikistan would be resolved by June 1997 due to the well-coordinated diplomatic efforts of both nations (Freedman, 1997, p. 106; Parker, 2008, p. 176), continuing pressure from Washington and the international community over arms cooperation and collaboration in developing Iranian nuclear technology as well as disagreements over Caspian Sea delimitation would 
function to moderate the overall level of cooperation between the two nations. Nevertheless, this period would continue to exhibit the same high level of cooperation that had defined the preceding five-year period thereby demonstrating the importance of their mutually beneficial relationship to one another.

Analysts have frequently pointed out that Russian-Iranian relations have generally been impacted by qualitative changes in each nation's overall relationship with Washington. This paper does not dispute that fact. Rather, it asks instead the question, 'what is the significance of third-party relations with Washington and other western powers on the political dyad when compared to national security concerns and changes in domestic politics?' Although pressure from Washington would cause Russian leaders to pursue policy options that would otherwise continue to strain bilateral relations during this era, it is simultaneously the case that this same period would demonstrate a great deal of bilateral political affinity between Russia and Iran, even leading Parker to conclude that 1997 had been the high point of bilateral relations (Parker, 2008, p. x). The push by Washington on Moscow to curb the proliferation of restricted technologies certainly intensified during this period but, as will be shown, did not apparently restrict the ongoing level of cooperation in conventional weapons and nuclear technology.

In April 1997 Majlis Speaker, Nateq-Nuri, visited Moscow in what had until then been called the "highest level Iranian sojourn to the Russian capital since that by Rafsanjani in 1989” (Parker, 2008, p. 118). During this visit officials signed an important mutual agreement on export controls that had been pending since December 1996 
(Parker, p. 119). Although the agreement rhetorically sought to curb the proliferation of trade in restricted technologies, Kenneth Katzman of the Congressional Research Service (CRS) has noted that Washington remained highly concerned about the stability of Russian non-proliferation commitments during this period and briefed Russian officials (via the Gore-Chernomyrdin Commission) in September 1997 of ongoing violations of the non-proliferation regime by various Russian corporations (Katzman, 1998, p. 2); according to Katzman, "Vice President Gore said that a U.S.-Russian inquiry had uncovered a vigorous Iranian effort to obtain nuclear and ballistic missile technology from Russia" (Katzman, p.2). Katzman's report demonstrates that by 1998 U.S. officials had taken decisive action to induce Russian efforts to curb illegal proliferation signing into law the Fiscal Year 1998 Foreign Aid Appropriations Law which sought to "[cut] $50 \%$ of U.S. aid to the Russian government unless it [ended] nuclear or ballistic missile cooperation with Iran" (Katzman, p. 3). Similarly, beginning in April 1998, Washington began placing sanctions on "select" Russian corporations suspected of participation in illegal transfers of dual-use technology (Parker, p. 122).

As a response to such measures, the Russian government took overt and dramatic steps to convince Washington, and the international community, that it was complying with the non-proliferation regime. On January 28, 1998 Prime Minister Viktor Chernomyrdin signed Directive Number 57 which Parker notes was designed to "close loopholes in Russian anti-proliferation legislation” (Parker, 2008, p. 122). Just two months later in March 1998 the Yeltsin administration would take further public steps to 
restrict the flow of dual-use technologies by appointing Andrei Kokoshin as the Secretary of the President's Security Council (a presidential advisory group) (Parker, p. 120). According to Parker, Kokoshin would come to play a "active role in elaborating and implementing new export controls designed to impede the unsanctioned flow of weapons and technology to Iran" (Parker, p. 120). By May of 1998, the administration would take even more pragmatic steps to curb proliferation by issuing a directive which placed 'export control units' in all Russian firms working in the nuclear and missile-related industries (Katzman, 1998, p. 2) while also working to subvert underground procurement activities of Iranian agents inside Russia that were focused on obtaining "missile guidance systems and liquid-fuel booster technology" (Parker, p. 121). And by July of 1998, Parker indicates that President Boris Yeltsin would name Deputy Head of the Presidential Administration, Vladimir Putin, as Director of the Federal Security Services (FSB), "with what appeared to be a mandate to rein in that agency's reported collusion in the illicit transfer of dual-use technology and parts to Iran" (Parker, p. 130, 132-3). Citing a former Security Council staffer, Vladimir Lebedev, Parker writes that "Putin, while FSB head from July 1998 to August 1999, was the architect of Russian nonproliferation policy" (Parker, p. 134). And yet, despite high-profile Russian efforts to curb illegal proliferation, both the Yeltsin and Putin administrations would pursue policies which simultaneously undermined these efforts—-demonstrating a desire still to cater to Iranian procurement activities. 
In particular, a May 1998 decision to replace MinAtom Director, Viktor Mikhaylov, with Yevgeny Adamov, a former head of the Scientific Research and Design Institute for Energy Technologies (NIKIET), demonstrated the Yeltsin administration's willingness to take chances with the non-proliferation campaign (see Parker, 2008, p. 137-40). Citing Russian media reports, Parker notes that between 1992 and 1998 while working for NIKIET, Adamov had presided over unilateral deals with the Iranian government for the provision of technologies aimed at enriching uranium (Parker, p. 140). These activities would lead the U.S., just one year later, to sanctioning NIKIET for the "transfer of missile and nuclear technologies to Iran" (Parker, p. 138). Also noteworthy, was the decision of recently elected president Vladimir Putin in May of 2000 to amend a 1992 nuclear technology export control decree, which reportedly gave the "green light to MinAtom negotiations with Iran for three more nuclear power units" valued at $\$ 2$ billion USD (Parker, p. 138). Thus although both the Yeltsin and Putin administrations were clearly responsive to western calls to curb illicit proliferation, both governments simultaneously pursued policies that functioned to reassure Iranian officials of their ongoing commitment to cooperation in the nuclear sphere. The same was true regarding the longstanding trade in arms.

By 1999, Parker indicates that Moscow was becoming increasingly divided over the negative security implications associated with the continuation of the nation's decadelong support of defense-related goods to Iran, emphasizing especially how such technology could be used to harm Russian energy interests within the region (Parker, 
2008, p. 135-7). Nevertheless, despite protests to the contrary, the Kremlin appeared intent throughout the period on increasing the sale of conventional weapons. According to SIPRI records, between 1997 and 2001, Moscow would sign new agreements for the sale of towed guns, infantry fighting vehicle (IFV) turrets, anti-tank missiles, and helicopters (SIPRI-Arms Transfer Database). Deliveries on these contracts as well as existing contracts signed in 1991 (anti-tank missiles, IFVs, tanks), 1993 (diesel tank engines), and 1995 (anti-tank missiles) make this five year period one of the most robust eras of cooperation in terms of actual numbers of contracts being both signed and delivered on (SIPRI). But the most defining moment of Russia's ongoing commitment to the trade in conventional weapons came from a Russian Security Council announcement in March 2000 that indicated the Kremlin was considering backing out of its June $30^{\text {th }}$, 1995 commitment in the Gore-Chernomyrdin Commission to ending conventional weapons sales to Iran after 1999 (Parker, p. 143). By Parker's account, the Russian Federation had supported its decision citing the fact that it had only fulfilled $50 \%$ of its defense commitments to the IRI and needed until 2010 to complete them (p. 143). Thus while Washington may have made significant inroads towards curbing the proliferation of illicit technologies, the relationship in conventional weapons supply was clearly expanded. By November 2000, Russia would only further demonstrate its commitment to the ongoing conventional weapons relationship when officials announced that the Federation would formally withdraw from the Gore-Chernomyrdin Commission on December 1 (Parker, p. 143; Katz, 2006, p. 1). 
In March of 2001 President Putin hosted a summit in Moscow with Iranian reformist president Khatami, although both presidents would come to sign the Treaty on the Basic Elements of Relations and the Principles of Cooperation, Parker reveals that the treaty, itself, did not significantly alter the existing nature of bilateral relations and did not describe Russia and Iran as 'strategic partners' (2008, p. 209). Nevertheless, the summit was notable insofar as it clearly reinforced the Federation's decision to withdraw from the Gore-Chernomyrdin Commission as both leaders discussed future arms agreements valued at $\$ 7$ billion USD - thereby demonstrating considerable political amity between the two nations (Parker, p. 209).

In terms of the ongoing question of Caspian Sea delimitation, this period represents a significant emerging challenge to bilateral cooperation as the Russian government moved away from consensus with Iran. Although both Russia and Iran had continued — officially — to endorse a jointly-authorized, condominium approach to living and non-living resource utilization with an excepted 45 off-shore exclusive zone and a jointly navigable sea surface, beginning in 1998 the Yeltsin administration made a decisive step towards an alternate delimitation regime. In July 1998, the administration formally agreed to open negotiations with Kazakh officials over a new regime known as the Modified Median Line (MML) (Ghafouri, 2008, p. 88; Parker, 2008, p. 157). According to Ghafouri and Parker, a MML division of the Caspian Sea sought to divide the seabed into sovereign national sectors based upon a median line that was consistent with national coastlines, leaving both the sea surface and water column freely navigable 
by all parties (Ghafouri, p. 87-8; Parker, p. 157). While Russia and Kazakhstan would not formally sign a delimitation agreement implementing this change of protocol until May of 2003 (Ghafouri, p. 88), the opening of negotiations prompted Iranian protests which surely functioned to strain bilateral relations.

Iranian dissatisfaction with the MML approach was likely a product of two key revisions to the existing delimitation regime. In the first instance, while a condominium approach to resource utilization effectively ensured each nation's participation in all E\&P activities outside of the exclusive off-shore economic zones—-by investing each nation with veto power over project development—-the new MML approach divided the seabed into unequal national sectors that were to be considered sovereign territory (Parker, 2008, p. 151-2; Ghafouri, 2008, p. 88). As Parker has noted, the condominium principle of resource utilization in the post-Soviet era would have encouraged all littoral states operating E\&P projects to include both Iran and Russia into their operations as a way of avoiding costly vetoes by both nations (Parker, p. 151-2); under an MML regime, Iranian and Russian participation was no longer guaranteed. Secondly, an MML approach maximized the potential economic gains of North Caspian nations like Azerbaijan, Russia, and Kazakhstan which were more likely to prosper owing to their lengthy coastlines, abundant resources, and shallow waters (a contingency which functioned to reduce project costs) (Parker, p. 151-2). In contrast, under an MML approach southern nations like Iran and Turkmenistan had significantly shorter coastlines which meant they could legally claim a smaller share of the seabed (Parker, p. 151-2). The negative impact 
of the MML regime was only further amplified by the fact that the Southern Caspian was generally less abundant in hydrocarbon resources and was considerably deeper making production costs more prohibitive.

The value to Iran of a condominium approach cannot be overstated when one considers the context of ongoing political relations between Iran and the United States at this time. In response to Iranian nuclear ambitions and its support for regional terrorist organizations, President Clinton signed into law the Iran-Libya Sanctions Act (ISA) in 1995, which "banning U.S. trade with and investment in Iran," also sought to, "curb the strategic threat from Iran by hindering its ability to modernize its key petroleum sector, which generates about $20 \%$ of Iran's GDP” (Katzman, 2007, p. 1). This act was immediately followed up with the Iran Foreign Oil Sanctions Act (IFOSA), which required the U.S. president to apply U.S. sanctions against foreign firms that provided Iran with energy-related technology (Katzman, p. 2). Under these sanctions, third party corporations choosing to invest more than \$20 million USD in Iranian hydrocarbon projects would be effectively prevented from doing business with U.S. based entities (Katzman, p. 2). The ability of Iran to veto the national E\&P projects of other Caspian littoral states under a condominium regime could conceivably provide the IRI with enough leverage over its neighbors to effectively ensure that the U.S. decree would be ignored among Caspian nations. On the other side of the equation, Caspian littoral states required the technical assistance of Western corporations for the development of the Caspian's hydrocarbon resources and so could not reasonably afford to ignore 
Washington's decree; by rejecting a condominium approach in favor of the MML regime, newly independent Caspian littorals could effectively insulate themselves from mandatory participation with Iran in hydrocarbon E\&P activities. Thus Russia's 1998 push toward MML negotiations with Kazakhstan not only functioned to practically restrict the sheer amount of hydrocarbon resources available to Iran but, perhaps more importantly, demonstrated to the Iranian leadership that the Kremlin would be hesitant to side with Tehran in its diplomatic war with the United States whenever the question of hydrocarbon resources was raised.

Tensions between Iran and other Caspian littorals grew substantially in 2001 as Iran began to officially pursue its own delimitation regime known as the $20 \%$ Equal Share Division (ESD). Beginning in March 2001, the Iranian Oil Ministry formally entered into an agreement with a Swedish firm GVA over the construction of a deepwater drilling rig that was to be located in Iran's unilaterally-claimed national sector (Parker, 2008, p. 158). Not entirely dissimilar from the MML approach, the ESD regime simply divided both the sea bed and surface into five equal national sectors (Ghafouri, 2008 , p. 89). Not only would this approach increase Iran's seabed territory from $13 \%$ of the Caspian under the MML regime to a proposed 20\% share, but it also sought to nationalize the sea surface thereby subjecting naval transportation within the sea to the regime of state sovereignty (Ghafouri, p. 89; Parker, p. 151-2). Iran's desire to pursue an ESD approach was clearly an affront to the Russian Federation which operated the sea's largest naval force and, as Ghafouri and Parker note, had been free to navigate the sea 
surface under both the condominium and MML approaches to delimitation (Ghafouri, p. 89; Parker, p. 162).

By January 2001, Azerbaijan had agreed, in principle, to Russia and Kazakhstan's mutual approach toward delimitation, thereby establishing a viable consensus among a majority of Caspian littorals (Parker, 2008, p. 160). The definitive change in Azerbaijani policy orientation brought the issue of Caspian delimitation to the fore as Azerbaijani claims under the MML came into conflict with Iranian claims under ESD. In July of that same year, Iran officially protested Azerbaijan's E\&P activities in the Alborz/Alov fields claiming that they violated Iran's national sector-an argument which resulted in the Iranian navy's intimidation of two British Petroleum (BP) research vessels on loan to the State Oil Company of the Azerbaijani Republic (SOCAR) (Parker, p. 158).

Although 2002 would come to represent the lowest point in Russian-Iranian agreement on Caspian delimitation since 1935, the case can quite clearly be made that cooperation in this area was effectively ended by 2001 . Notably, Parker indicates that it was in this very same year-under the administration of Vladimir Putin-that 'government representatives' first gained a controlling number of seats on the Gazprom board (a partially-privatized state natural gas monopoly) (Parker, 2008, p. 148). The de facto renationalization of Gazprom and subsequent moves by the Russian state to control the formation of energy policy among post-Soviet nations in the coming years would only further place both Russia and Iran at odds with one another as both sought to assert control over regional hydro-carbon exports (Freedman, 2001, p. 71). 
2002-2006: Cooperation vanishing

Average GPA Score for Period: 11.59, Moderate-Level of Moderate Cooperation

Disagreements over Caspian delimitation had certainly strained bilateral relations in the preceding period as each nation was forced to redefine its preferred policy position in the post-Soviet era; and yet, despite increasing pressures from the international community over security-related concerns, trade in conventional arms and cooperation in the field of nuclear science had remained relatively robust thereby preserving a clearly moderate level of political affinity. But the continuation of political affinity would be severely challenged following revelations in 2003 and 2004 that Iran had been secretly working towards the enrichment of uranium. While the regime would claim that the domestic enrichment of uranium was part of a larger goal of developing an independent nuclear fuel cycle for the generation of peaceful nuclear power, continued failings of the Iranian leadership to publicly disclose the status or intentions of its program-as well as its generous reserves of natural gas which could also be used to produce electricityundermined the faith of the international community. Russian diplomatic support as well as its ongoing technical cooperation in the nuclear field, no doubt, served to buoy political relations in this period, but already there were signs that the partnership was growing increasingly fragile-further drift in the Caspian delimitation regime, the signing of only a few new agreements for conventional weapons, and delay over the 
Bushehr nuclear power plant's completion were concrete signs that political collaboration was now in increasing jeopardy.

Between 2002 and 2006 the trade in conventional weapons between the two nations had continued without significant interruption but it was already clear that cooperation was on its decline. According to SIPRI records which denote the number of new and existing conventional weapons contracts in any given year, it can clearly be shown that during this period—although the arms trade was still robust—it was, in fact, beginning to lag. Taking the average annual number of contracts being both signed and delivered on for consecutive five-year periods, figure 2 (below) demonstrates not only the subtle trade decline experienced during the period 2002-06 but also the more significant reduction that was soon to occur in this study's closing period 2007-10.

Between 2002 and 2006 the Russian Federation and Islamic Republic would sign four new contracts for short range anti-aircraft missiles (SRAAM), ground attack

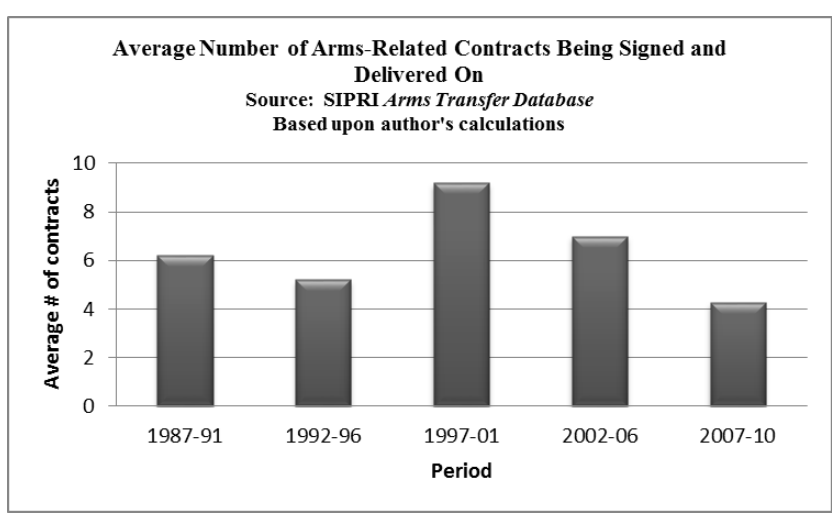

Figure 2: Average Number of Arms-Related Contracts in Successive 5-year periods (1987-2010). systems, surface-to air-missiles (SAM), as well as mobile SAM systems (SIPRI Arms Transfer Database). Meanwhile Moscow would continue its deliveries on previously signed contracts for antitank missiles (up through 2010), 
diesel engines for tanks (up through 2003), towed guns (up through 2002), IFV turrets (up through 2010), and helicopters (up through 2003). Despite the subtle decline in the conventional weapons trade during this period there were no other significant developments.

Regarding Caspian Sea delimitation, the 2002-06 period demonstrated the further consolidation of national positions advanced in the preceding era as well as the emergence of a decidedly conflictive disposition in Russian-Iranian relations. Between April and May of 2002, Russian president Vladimir Putin would not only officially reject Iran's ESD approach to Caspian delimitation, but would also sign a completed delimitation agreement with Kazakh president Nursultan Nazarbayev based upon the MML approach to demarcation; by September president Putin would sign a similar bilateral agreement with Azerbaijani president Heydar Aliev (Parker, 2008, p. 161). Although these agreements did not establish a new formal consensus on Caspian delimitation among all littoral states, they did suggest Russia's de facto reversal of the traditional cooperative regime which had been adhered to by both nations since the treaty of 1935.

The signing of official bilateral delimitation agreements in the spring and fall of 2002 can be linked to a Russian policy change on hydrocarbon resource development in the Caspian basin and Central Asia which that had been officially endorsed by Putin in January of 2002 and which clearly placed Russia and Iran at increasing odds with one another. By Parker's account president Putin had unveiled a new plan in January of 2002 
aimed at incorporating Central Asian nations into a natural gas cartel or 'alliance' that was to be spear-headed by the Russian Federation and which would aim ultimately to control the flow of regional hydro-carbon exports to expanding markets in Europe and Asia (Parker, 2008, p. 149). Notably, Parker indicates that Putin's project-at least in part—sought to undermine Iran's own efforts to capture the downstream European market. Parker writes:

The project aimed at a Gazprom monopoly on less expensive Central Asian natural gas exports in order to greatly increase Gazprom's profit margin in lucrative European markets. Together with the Blue Stream pipeline to Turkey, Putin's Gazprom-led 'alliance' cemented Russia's position as the dominant supplier of natural gas to much of Europe and blocked Iran from any attempt to move in and whittle down Russia's market share (Parker, 149).

Possessing 991.6 trillion cubic feet (tcf) of natural gas, Iran holds the world's second largest reserves and so clearly presented a challenge to the Russian Federation which - through the partially-privatized multinational corporation Gazprom-both possesses the world's largest natural gas reserves (1,680 tcf) and operates the world's most extensive pipeline transit system known as the Unified Gas Supply System (UGSS) (Statistics, U.S. Energy Information Administration "World Proved Reserves of Oil and Natural Gas").

While the petroleum industry had accounted for $25 \%$ of federal government revenue in 1998 on the eve of Putin's presidency, independent reports indicate that by 2008 energy receipts would come to account for fully $50 \%$ of all federal revenuesthereby demonstrating the increasing importance of energy to matters of Russian state 
policy during this and later periods (Kwon, 2006, p.2; Foglizzo, 2008). Given the fast increasing importance of energy receipts to federal coffers there can be little doubt that matters of energy export were becoming increasingly salient in terms of bilateral cooperation.

Surely there can be no coincidence that Putin's January 2002 announcement of a Central Asian gas alliance had followed the December 2001/January 2002 opening of the rival Tabriz-Ankara natural gas pipeline which functioned to transport natural gas supplies from Iran (and potentially Eastern Caspian littoral nations like Turkmenistan) to Turkey and on to Europe (BBC 2006, November 2; Parker, 2008, p. 154). By Parker's account, the Iran-Turkey line presented the first credible challenge to Russia's hegemony over regional exports (Parker, p. 154) and so acted as a considerable threat to a state which was in the process of deepening its dependency upon energy-related revenues. Thus there can be little doubt that the emerging competition over energy resources and their distribution to downstream markets placed a significant strain on bilateral relations in this period and was likely the basis for the growing divergence over issues of Caspian delimitation.

Noteworthy also is the fact that less than two weeks after the signing of bilateral delimitation agreements between Russia and Azerbaijan in September 2002, the Russian Navy conducted what Parker has referred to as an "unprecedented" military exercise in the Caspian, perhaps demonstrating to all nations the critical weight which Moscow's leadership was now assigning to the control of regional energy exports (Parker, 2008, p. 
162). According to Parker, these exercises had deeply concerned the Iranian leadership, he writes, "[Iranian] advisers feared that Russia wanted to maintain a condominium approach to the Caspian's surface so that Russia's Caspian flotilla—substantially larger than Iran's - could exercise 'hegemony' over the other four littoral states" (Parker, p. 162).

Throughout the remainder of this period, Russia would come to consolidate its control over the direction of regional gas exports by signing a series of bilateral production agreements in the Eastern Caspian and Central Asian region; through these agreements Moscow would effectively lock-up regional supplies thereby preventing their export through competing Iranian (Tabriz-Ankara) or U.S.-backed pipelines (Nabucco). In April 2003, September 2005, and November 2005 Parker indicates that Russia's Gazprom Corporation would conclude successive long-term gas production and transit agreements with Turkmenistan, Uzbekistan, and Kazakhstan that would effectively provide Moscow with virtual control over the region's natural gas reserves (Parker, 2008, p. 283). Following these acquisitions in June of 2005, the Russian state purchased 2.5 billion additional shares of Gazprom stock which provided the Russian state with a $50.002 \%$ controlling interest - the largest concentration of state-owned stock in Gazprom since its privatization in the early 1990s (See Appendix Table A. 1, figures supplied by Gazprom; Parker, 2008, p. 283). Parker indicates that by 2006 Gazprom would largely come to control nearly all gas exports to countries in Eastern Europe and would control substantial portions of gas supplies used by the EU's predominant powers such as 
Germany and France (44\% and 25\% respectively) (Parker, p. 283). Russia's European position was only further enhanced during this period by the efforts of Kremlin-friendly corporations to acquire controlling interests in downstream Central and Eastern European energy assets (pipelines, refineries, petro-chemical plants, and retail outlets) which effectively provided Moscow with increasing control over the sourcing of imports (See Bugajski, 2008). This activity only further functioned to isolate other Caspian producer nations from downstream energy markets and therefore would likely have added increasing strain to Russian-Iranian relations.

That Russia's new Caspian delimitation regime also functioned to enhance Moscow's control over regional energy production and exports—and hence the stability of its downstream markets-seems likely. More importantly, Moscow's changing attitudes towards the importance of Caspian and Central Asian energy in this period clearly placed Russia and Iran into increasingly competitive positions. As mentioned in the preceding section, Russia's transition to a series of Caspian delimitation agreements based upon the MML principle functioned both to isolate Iran from the maritime production activities of other littoral nations as well as to restrict Iran's overall share of the Caspian to a small percentage of the seabed and water column consisting of fewer harder to reach hydrocarbon reserves. Simultaneously, the MML's insistence on maintaining free mobility of the sea-surface likely preserved the Russian navy's right to protect future joint venture projects in disputed territories from interference by aggrieved Caspian littorals such as had been the case between Iran and Azerbaijan during 2001. 
But the strain hydrocarbon resources were placing on bilateral relations during this period was not the only important development; revelations during this era that Iran was, in fact, seeking to develop a domestic nuclear fuel cycle would only further ignite international criticism of bilateral cooperation in nuclear science and technology.

Although future nuclear cooperation appeared promising in December of 2002 with discussions between Russia's MinAtom and Iran calling for evaluations of the construction of a second nuclear reactor, that same month a Washington-based, Iranian opposition group disclosed reports based on commercial satellite imagery that suggested Iran was both enriching uranium at the site of Natanz and making 'weapons-grade' plutonium in Arak (Parker, 2008, p. 215-17; Katz, 2006, p. 1). According to Parker, Iranian president Mohammad Khatami responded to these charges indicating that Iran was, in fact, attempting to develop the technology that would enable it to produce a complete 'indigenous' nuclear fuel cycle that could be used to fuel as many as six nuclear reactors engaged in the production of electricity (Parker, p. 217). Analysts have frequently suggested that Iran's comparative advantage in natural gas (which is commonly used in the production of electricity) should preclude the need for developing highly controversial nuclear technology; thus the argument is made that Iran is likely invested in developing nuclear power for use in military applications (Saberi, 2006, August 1). Although the argument is not without some level of merit, Iranian officials have expressed the idea that nuclear power generation would not only preserve Iran's 
non-renewable hydrocarbon resources, but from an economic standpoint would also free up more reserves for production and export (Saberi).

Iran's admissions prompted a visit by International Atomic Energy Agency (IAEA) Director General El Baradei to Iran in February 2003. According to Parker, El Baradei's report confirmed that Iran had installed 100 gas centrifuges to be used for the enrichment of uranium, further noting that the IRI had plans to develop an additional 50,000 centrifuges at the Natanz facility (Parker, 2008, p. 217). The admission had clearly placed a strain on bilateral relations as was evident by Russia's decision to support the June 2003 Joint Declaration of the G-8 Summit which urged Iran to formally agree to an IAEA additional protocol (Orlov \& Vinnikov, 2005, p. 55). The degree of strain, however, appears to have been only slight insofar as Russian president Vladimir Putin agreed to continue cooperation in the nuclear sphere, provided Iran was willing to allow its operations to be overseen by the IAEA (Parker, p. 220-1). In the wake of such events Iran appeared clearly willing to cooperate and so delivered a full disclosure of all of its nuclear programs to the IAEA (October 2003) while also signing an IAEA protocol requesting the "temporary and voluntary" suspension of all enrichment activities (Parker, p. 253).

While such moves clearly diffused some of the tensions weighing upon bilateral relations and so provided a reasonable basis for continued cooperation in the development of the Bushehr facility there were signs that members of Russia's policy community were becoming increasingly distrustful of continued cooperation. Orlov and 
Vinnikov indicate that an October 2003 Ministry of Defense report had, "listed Iran, alongside North Korea, as a country with an 'unclear status' as far as a nuclear weapons program was concerned" (2005, p. 55). While the Ministry of Defense's position did not fully represent Moscow's thoughts on cooperation with Tehran it did represent a significant sub-sector of the government that had long been skeptical of bilateral cooperation. According to Parker, in December 1996, amid a flurry of western criticism over cooperation in conventional weapons, Russia's Defense Minister, Igor Rodinov, "had included Iran among countries that represented an increasing military danger" (Parker, 2008, p. 120). The layers of distrust within Russia's policy community seemed only to deepen, however, following revelations at the Natanz facility. Orlov and Vinnikov have written, "An internal decision seems to have been made at some point between 2002 and 2003 not to speed up the full completion of the Bushehr nuclear power plant project, invoking technical reasons" (Orlov \& Vinnikov, p. 55). Thus while cooperation continued, the revelations of 2003 likely were functioning to restrain the scale of future collaboration as evident through completion delays.

By early 2004 IAEA investigations had discovered efforts by Iran to conceal the construction of a "more advanced centrifuge design" known as the P-2 (Parker, 2008, p. 254). The G-8 once again took up the issue in the June Summit, this time issuing a declaration, signed by Russia, which "aimed at ending nuclear fuel cycle cooperation with states that violate their nuclear non-proliferation and IAEA safeguard obligations..." (Orlov \& Vinnikov, 2005, p. 55). In the wake of the Summit Iran fully acknowledged 
that it had not suspended its nuclear enrichment program and had been actively building centrifuges and seeking out 37 tons of yellowcake for nuclear fuel production (Parker, p. 254). By November 2004, Iran would sign an agreement with the EU-3 (France, Germany, and UK) agreeing to fully suspend its enrichment activities in an interim period of negotiations (Parker, p. 255). The decision to cooperate with the EU-3 appears to have once again paid dividends in terms of Russian-Iranian cooperation as by December 2004 both nations had "launched discussions on the possible construction of up to seven more nuclear power plants totaling 6,000-7,000 megawatts of power" (Orlov \& Vinnikov, p. 60-1).

Moscow continued to deepen its nuclear cooperation with Iran in the wake of the December agreements with the EU-3. While both nations would sign an important spent fuel return agreement in February 2005 which called for the release of all spent nuclear fuel to Russian authorities for further disposal, Russian officials would take additional steps to demonstrate considerable diplomatic support for continued cooperation with Iran (Katz, 2006, p. 1; Parker, 2008, p. 255). That same month Russia would use its veto power as a permanent member of the United Nations Security Council (UNSC) to formally reject U.S. calls for imposing related international sanctions and by July 2005 would welcome Iran as an observer into the Central Asian regional security regime- the Shanghai Cooperation Organization (SCO) (Parker, p. 256, 281).

Shortly after Iran's entrance into the SCO as an observer, on August 1, 2005 the IRI notified the IAEA that it would resume uranium conversion; just two days later neo- 
conservative Mahmoud Ahmadinejad would be elected to the Iranian presidency (Katz, 2006, p. 2; Parker, 2008, p. 256). The new presidential administration of Mahmoud Ahmadinejad represented a decisive reorientation away from the reformist policies of the previous administration and was more ideologically aligned with the former revolutionaries of the Khomeini era which favored policies of aggravation towards the west (Rakel, 2009, p. 122). Just one month later on September 17, 2005, in an address to the UN General Assembly, president Ahmadinejad defended the IRI's right to domestically produce a complete nuclear fuel cycle indicating that international contracts of fuel delivery were highly unreliable and not legally binding (Parker, 2008, p. 258). Parker indicates that, "The immediate shift in Iran's negotiating posture with the EU-3 forced Moscow to adjust its own approach" (Parker, p. 256). Between September 2005 and June 2006 Russia would pursue an increasingly complex policy designed to balance its relations with both Iran and the international community. While some tangible signs of political affinity would still remain, it was simultaneously true that Russia's diplomatic support for the IRI was growing increasingly thin.

Shortly after Ahmadinejad's speech before the United Nations, the IAEA decided to turn the issue over to the UNSC. Despite the fact that both Russia and China had abstained from the IAEA vote thereby allowing the issue to pass to the UNSC, in November 2005, Moscow proposed a concessionary plan that would allow Iran to temporarily continue enrichment activities so long as it remained committed to finding a permanent solution in the context of ongoing EU-3 negotiations (Parker, 2008, p. 258). 
Russia offered further enticements to the IRI leadership by simultaneously signing additional agreements for Pechora-2A SAM systems, as well as agreements on the sale of 29 or 30 Tor-M1 air defense systems valued at \$1billion USD, while agreeing also to aid Iran in the launching of an Iranian remote-sensing spy satellite (Katz, 2006, p. 3; Parker, p. 260). Although new arms agreements were clearly on the table, Russia was also becoming increasingly supportive of efforts which pushed the nuclear issue before the UNSC. In February 2006 just one month after Iran announced that it had resumed enrichment activities at the Natanz facility, Russia would support an IAEA Board of Governor's decision to supply the UNSC with Director El Baradei's findings and recommendations (Katz, 2006, p. 3; Parker, p. 261). While Russia would initially oppose any talk of imposing sanctions on Iran within the UNSC/P5+1 setting during March, tensions were clearly building as the Russian Foreign Ministry publicly denounced Iran's mismanagement of the highly contentious issue (Katz, p. 3; Parker, p. 263).

A fundamental turning point in bilateral relations came in late June 2006, however, when the Iranian president formally rejected a generous settlement from the EU-3 which, according to Parker, would have provided the IRI with increasing access to international capital, investment, and markets (Parker, 2008, p. 268-9). Having failed to concede to the highly generous conditions of the EU-3 negotiations, Russia seems to have largely abandoned its commitment to continued diplomatic support for the IRI. Beginning on July 31, 2006 the UNSC adopted Resolution 1696 which called for the imposition of sanctions if all enrichment activities were not ended within thirty days 
(Katz, 2006, p. 4; Parker, p. 250, 270). Failing to concede to the UNSC's demands, the council passed Resolution 1737 in December 2006 which called for the beginning of international sanctions (Parker, p. 301).

With cooperation on the issue of Caspian delimitation effectively ended and cooperation in the nuclear sphere collapsing, it was clearly the case that by the end of 2006 bilateral relations were now entering a state of general decline.

2007-2011: State of decline Average GPA Score for Period: 8.16, Low-Level of Moderate Cooperation

The period of 2007-11 would prove to be one of quickly worsening conditions between the two nations. The status of bilateral relations had been confirmed early on in January 2007 when Russian president Vladimir Putin dismissed the Ayatollah Khamenei's calls for a new "strategic alliance" in regional affairs (Parker, 2008, p. 302). While president Vladimir Putin would visit the IRI later that same year in October 2007-the highest ranking visit of a Russian leader to Iran since 1943 (Parker, p. 305) relations on all three issues were in a clear state of decline thereby confirming the fact that the high-level of affinity of the 1990s was now nearly at its end. Putin's visit to Tehran had entailed a summit on Caspian affairs as well as a series of meetings with both president Ahmadinejad and Supreme Leader Ayatollah Khamenei; by Parker's account both sets of meetings had proved themselves largely unremarkable (Parker, p. 305). On the issue of Caspian delimitation, Parker indicates that not only did the summit simply 
'paraphrase' previous non-aggression language from earlier bilateral treaties, but more important still it failed to resolve the essential question of Caspian delimitation (Parker, p. 305). In a similar fashion Parker notes that calls for long-term economic, industrial, scientific, and technical cooperation unveiled no new concrete initiatives and "merely resurrected the negotiations apparently dropped after 2003" (Parker, p. 305).

And although cooperation in Caspian and nuclear affairs had largely collapsed in recent years, the previous period (2002-06) had been notable for the continuation of the dyad's long-standing relationship in the trade of conventional weaponry. While there had been a marked decline in the number of active contracts in the previous term when compared to earlier eras, until 2007 the trade in arms continued largely uninterrupted. And yet between 2007 and 2011 even the trade in conventional weapons would effectively dry-up thereby leaving a general deficit in all levels of political affinity between these two nations.

Between 2007 and 2010 Russia would continue to fulfill long-standing contracts for the delivery of Anti-Tank Missiles (signed in 1991, 1995, and 1998) and turrets for Infantry Fighting Vehicles (signed in 1999), as well as its more recent agreements for the Tor-M1 air defense system (signed in 2005) (SIPRI, Arms Transfers Database). While deliveries on Anti-Tank Missiles and Turrets would continue through 2010, deliveries on the Tor-M1 were quickly concluded by 2007 (SIPRI). Most importantly of all, this period was remarkable for the simple fact that only one new conventional arms agreement had been signed between both nations. The general deficit of both new and 
existing contracts indicate a substantial reduction in the conventional weapons trade, the likes of which had been unknown since general rapprochement had occurred in the late 1980s (See figure 2 in previous section).

The single new contract agreed to in 2007 was for the $\$ 800$ million sale and delivery of Russia’s S-300 long-range air defense missile system (Parker, 2008, p. 309; Kessler and Richburg, 2010, June 12). According to Parker, the sale of the S-300 was highly significant insofar as it would provide Iran with the ability to defend its nuclear installations at Bushehr and Natanz from high-altitude stealth bomber attacks (Parker, 2008, p. 303). According to a UPI report, "The S-300 is considered one of the world's most advanced air-defense systems...[And] can engage multiple targets, missiles as well as aircraft, at ranges of more than 100 miles at low and high altitudes" (UPI, 2011, August 30). While the announcement of the contract was clearly a significant political development, further complications related to Iran's nuclear enrichment program cut short the delivery of this critical weapons system (Katz, 2010, p. 17).

In particular UNSC Resolution number 1929 (dated June 9, 2010) paragraph 8 explicitly called for expanding international sanctions against Iran to include the "direct or indirect supply, sale or transfer" of conventional weapons by all nations (United Nations Bibliographic Information System-UNBISNET). According to the Glen Kessler and Keith B. Richburg of the Washington Post officials from the Russian Foreign Ministry had originally suggested - just one day after the vote - that deliveries of the S300 system would not be affected by the new round of sanctions (Kessler \& Richburg, 
2010, June 12). Kessler and Richburg indicate that the Foreign Ministry's initial assertion had been based upon the fact that a "loophole in the language of the resolution suggested that defensive ground-to-air missile systems such as the S-300 were not covered by the ban" (Kessler \& Richburg). Notably, just two days after the event, the Kremlin contradicted the Foreign Ministry's statements indicating that the language of the resolution did, in fact, apply to the sale of the S-300 systems thereby committing the Russian Federation to upholding the new round of sanctions and suspending delivery of the S-300 system (Kessler \& Richburg).

Kessler and Richburg further suggest that Russia's policy reversal may have been contingent upon warming ties between Moscow and Washington insofar as it occurred on the same day the White House announced a June 24, 2010 summit between presidents Obama and Medvedev to be held in Washington (Kessler \& Richburg, 2010, June 12). Whatever had been the cause of the collapse of the S-300 deal, it should be recalled that general cooperation in conventional weapons sales was already in a significant state of decline by 2010 as evidenced by the dearth of new contracts. Most important is the fact that throughout this era Moscow appeared both unwilling to continue its prior level of commitments in weapons cooperation and now appeared simultaneously willing to endorse a resolution ending arms ties that had extended back to 1989. While it may be tempting to note that a growing rapprochement with Washington was responsible for this changing policy, it is prudent to recall that the high-level Gore-Chernomyrdin Commission-itself a longstanding symbol of cooperative relations between Moscow and 
Washington — had been unable to dissuade Russia from collaborative arms contracts with Iran; such examples tend to suggest an alternate reason for cooperative decline rather than one based simply upon third party relations with Washington.

More than a year after the Kremlin's decision to suspend deliveries of the S-300 under sanctions imposed by UNSC Resolution 1929, Iran's ambassador to Moscow on August 24, 2011 formally rejected Russia's official position declaring that S-300 deliveries did not, in fact, violate the terms of the 2010 resolution (UPI, 2011, August 30). Having reportedly made an early down payment of $\$ 170$ million following the contract signing in December 2007, Iranian officials became subsequently engaged in a legal battle to force Russia to abide by its contractual commitments (UPI, 2011). According to UPI, on June 30, 2011 the IRI filed a lawsuit in the International Court of Justice seeking to resolve the differing interpretations of the resolution's provisions and so win a judgment that would compel Russia to begin system deliveries (UPI, 2011). Notably, Iran's legal battle appears to parallel a recent 2011 push by Israeli Prime Minister Benjamin Netanyahu to gain domestic approval for Israeli air strikes against Iranian nuclear facilities (Telegraph, 2011, November 2); as mentioned previously, numerous sources indicate that the S-300 system would provide Iranian nuclear facilities with a robust line of defense against air to ground attacks (Parker, 2008, p. 303; UPI, 2011).

Iran's appeal to an independent court as well as Russia's continued willingness to abide by existing international sanctions are, themselves, clear evidence of the widening 
rift in bilateral relations. Still, UPI notes that Moscow's future position on the issue will likely depend upon how it views its relations with both Iran and Washington and, citing a report by Stratfor, suggests that Moscow could, quite easily, subvert international sanctions if it chose to by channeling S-300 sales through other defense clients such as Belarus, Armenia, or Kazakhstan (UPI 2011, August 30). Complications pertaining to the sale and delivery of the S-300 system were not surprising, of course, given the overall declining state of cooperation that was becoming quickly evident in the nuclear field.

Where Moscow once appeared a robust and cooperative ally in Iran's quest to develop nuclear power, leaders in the Kremlin during the period 2007-11 proved also that Russia held no fundamental allegiance to Iran or to its own history of seemingly unconditional support. Although nuclear cooperation between the two would appear to regain some of its former vitality by the fall of 2011, between 2007 and spring of 2011 Russia and Iran's relationship would be sorely tested as the international community became increasingly concerned at Iran's intentions.

According to United Nations records, between 2007 and 2010 the Russian Federation would support three more rounds of sanctions against the IRI in the UNSC forum (Res.1747 March, 2007; Res.1803 March, 2008; Res.1929 June, 2010) (UNBISNET). Failing to heed international calls for the suspension of nuclear enrichment activities, Parker indicates that Russia's Security Council in March of 2007 notified Iran that it would now make anticipated nuclear fuel deliveries contingent upon the IRI's cessation of its enrichment program (Parker, 2008, p. 303). Importantly, Parker 
also indicates that the Kremlin, once again, in the summer of 2007 began to slow down the completion of the Bushehr facility as a means for increasing its own political leverage over Tehran. He writes:

Subsequently, after charging Tehran with falling behind on its payments, Moscow cited technical disruptions in explaining a further delay in the target date for the completion of Bushehr. When the original contract had been signed in October 1995, Bushehr had been projected to be finished by spring 2000. By summer 2007 Bushehr's completion date had slipped to fall 2008 at earliest (Parker, p. 303).

Construction delays would continue throughout much of this period as Iran repeatedly undermined calls by the international community to suspend its enrichment program. Ongoing project delays would, ultimately, push the completion of the Bushehr project back to summer of 2010 when both Russian and Iranian officials jointly began loading fuel rods into the reactor on August 21, 2011-a step which formalized Bushehr's classification as an official nuclear facility (Makarova \& Kevorkova, 2010, August 20). During this period the Kremlin sought out other ways of increasing its leverage over a still-defiant Tehran. While the advertised suspension of S-300 sales in August 2010 was a clear effort to reign in Tehran's behavior following expanded UNSC sanctions that June, the Kremlin also had made use of its leverage against Tehran in the Shanghai Cooperation Organization (SCO).

During the 2010 SCO Heads of State meeting in Tashkent, Uzbekistan (just days after the expanded 2010 sanctions) Russian president Dmitri Medvedev announced that no country under UNSC sanctions would be eligible to become a full-member nation of 
the SCO (Kessler \& Richburg, 2010, June 12); clearly the announcement had been aimed at the IRI which presently held 'observer' status within the SCO. As if expressing frustration with the Russian leadership's earlier decision to suspend S-300 sales, Iranian president Mahmoud Ahmadinejad was conspicuously absent from the 2010 SCO annual meeting, traveling instead on an official state visit to Beijing (Kessler \& Richburg) notably, the presidents of fellow observer nations Pakistan and Afghanistan were, in fact, in attendance at the Tashkent summit meeting (see Kremlin website: http://eng.kremlin.ru/visits/421). Ahmadinejad's well-timed trip to the PRC would appear to be an overt symbol of the growing political ill-will between Moscow and Tehran in this period and may represent Iran's intention to replace lost Kremlin support with diplomatic support from Beijing. While political affinity has been a generally rocky road between Iran and Russia with many ups and downs over the years, Iran's relationship with China has generally been more stable, depending upon the long-term trade in both energy and weaponry (U.S. Energy Information Administration, Iran country profile; Katzman, 1998, p.3).

Despite the Kremlin's various efforts to restrain Iran's nuclear ambitions during this period, Moscow still managed to accommodate the further development of Iran's civilian nuclear program by supplying low-enriched uranium to be used as nuclear fuel for Iran's Bushehr facility between December 16, 2007 and January 28, 2008 (Parker, 2008, p. 307-8; Radio Free Europe/Radio Liberty, 2008, January 28). According to Parker, the decision to ship fuel to Bushehr represented a "clear reversal of long-standing 
policy" wherein Moscow has since 2003 repeatedly tied future fuel deliveries to the Iran's voluntary suspension of all enrichment activities and complete adherence to the IAEA's additional protocols (Parker, p. 308). Both Russian and Western officials (including the UN) have defended the delivery of low-enriched uranium (which cannot be used for nuclear weapons) indicating that such deliveries, in fact, negate Iran's need to continue its own domestic enrichment activities (Parker, p. 308; BBC, 2007, December 17). According to the BBC, although Russia continued to press Iran to suspend its enrichment program following the fuel delivery agreements, Iranian officials indicated that Iran "would not halt uranium enrichment under any circumstances" (BBC, 2007). Thus while the decision to begin fuel deliveries may in some sense be viewed as a positive bilateral development, Iran's continued defiance of Moscow's calls to suspend enrichment activities also remains a clear indicator of the ongoing tensions which plague bilateral relations in the nuclear field. Yet by the fall of 2011, the fragile state of nuclear cooperation that had defined the majority of the era appeared at an end as Russia for the first time since 2006 indicated that it would now be unlikely to support increasing sanctions against the IRI.

On November 8, 2011 the IAEA released a new report indicating that the IRI may, in fact, still be secretly pursuing the development of a nuclear weapon (Gutterman, 2011, November 9). In the wake of the report, officials in both the U.S. and France signaled that their respective governments would support the imposition of increasing sanctions against the IRI (both bilateral and multilateral rounds) (Gutterman). According 
to Steve Gutterman of Reuters Russian officials in the Foreign Ministry have rejected the report's claims indicating that no new information had been revealed and that Moscow would therefore not, in fact, support an expanded sanctions regime (Gutterman). Citing an Interfax report, Gutterman quotes Deputy Foreign Minister Gennady Gatilov saying that new sanctions "will be seen in the international community as an instrument for regime change in Tehran" mentioning further that "That approach is unacceptable to us, and the Russian side does not intend to consider such proposals" (as cited in Gutterman, 2011, November 9). The growing nuclear rapprochement was only further complemented by a joint announcement just two days later on November 11, 2011 that Russia was considering working with Iran to develop additional nuclear reactors (Faulconbridge \& Gutterman, 2011, November 11). Although no official agreements had been signed as of the time of this writing, Russia's increasingly positive public support for Iran's nuclear program should be viewed as a both highly significant event following roughly five years of diminishing affinity.

The time frame of 2007-11 can thus clearly be distinguished as a time of decreasing political affinity as cooperation over the sale of conventional weapons and nuclear development stalled and a general consensus on Caspian delimitation was still absent. And yet, the final months of 2011 appear to suggest that a growing restoration of cooperative relations may once again be on the rise as both Russia and Iran defend their nuclear partnership in the face of harsh criticism by the international community. 


\section{Chapter III \\ Measuring Bilateral Relations in the Post-Soviet Era: Constructing a composite dependent variable of General Political Affinity}

In an effort to simplify and make usable the complex information pertaining to the

Russian-Iranian political dyad developed in Chapter II, I construct a quantitative, multidimensional indicator of General Political Affinity (GPA) which measures annual changes in the overall quality of bilateral political relations between 1966 and 2011 .

By compressing complex dyadic data into a simple, scaled political indicator this study seeks to construct a well-informed and sensitive dependent variable which can be used to test the varying range of factors which can reasonably be expected to influence changes in bilateral relations. By creating a case-specific indicator, this study hopes not only to contribute a new and innovative means of measuring Russian-Iranian political affinity but more generally invites policy professionals to entertain the utility of political metrics as a means of standardizing the disparate voices of speculation that muddy the field of international affairs.

In the preceding chapter I sought to demonstrate the idea that 'General Political Affinity' between any set of nations is both highly nuanced and often depends upon a set of factors that are peculiar to that distinct political relationship. In the case of RussianIranian relations, relying upon a variety of sources, I have suggested that annual political affinity in the post-Soviet era is the product of changes in the trade of conventional weapons, cooperation in nuclear development, and agreement in matters of Caspian Sea 
delimitation. Although it is important for the sake of this study to focus on the specific set of factors comprising Russian-Iranian political relations, we can also inductively reclassify these specific factors into three substantive issue dimensions which could be used to develop a definition of General Political Affinity. In this manner I suggest that General Political Affinity (GPA) is likely the product of: 1) Defense Cooperation; 2) Inter-State Development Assistance; and 3) General Agreement on Territorial Divisions; operationalizing these three issue-dimensions would therefore be the task of the individual researcher/policy professional, a task which, as the preceding chapter has suggested, is best fulfilled by a comprehensive qualitative analysis of interstate relations.

Although it is reasonable to suggest that underlying factors do not all impact political affinity in an equal manner, it remains outside the scope of this present study to determine what varying weights should be assigned to each underlying issue dimension; such determinations, rather, are best made from a position of consensus involving multiple case studies. To avoid making excessive errors in the estimation of factor weights on overall political affinity, I therefore assume that all factors are weighted equally. As such, the final measurement of GPA is here represented as the sum of all underlying factors. 
For the sake of efficiency I have chosen to express each of the three underlying factors or issue dimensions in terms of a simple ordinal, 7-point scale ranging from 'strong non-cooperation' (1) to 'strong cooperation' (7) with an intermediary point of neutrality (4). While expressing each underlying issue dimension as a continuous variable would provide greater range and variation among scores, the decision to utilize a ordinal variable is here profitable as it enables the researcher to incorporate a wide variety of qualitative data into a simple format thereby diminishing one's reliance upon traditional numeric indicators which may not always adequately capture the essence of the issue dimension being analyzed. By translating all three underlying issue dimensions

\begin{tabular}{|c|c|c|}
\hline \multicolumn{2}{|l|}{ Category } & Numerical Value \\
\hline \multicolumn{2}{|c|}{ Strong Cooperation } & 7 \\
\hline \multicolumn{2}{|l|}{ Moderate } & 6 \\
\hline \multicolumn{2}{|c|}{ Basic Cooperation } & 5 \\
\hline \multicolumn{2}{|c|}{ Neither Cooperation } & 4 \\
\hline Basic & Non- & 3 \\
\hline Moderate & Non- & 2 \\
\hline
\end{tabular}
into uniform ordinal variables, the product of General Political Affinity may simply be expressed as the sum of all three data points on a 21 point scale.

Table 1: 7-Point Scale for Sub-Components of GPA.

\section{Measuring Defense Cooperation: Annual cooperation in the trade of conventional} weapons (ACTW)

I operationalize Defense Cooperation as annual cooperation in the trade of conventional weapons, relying upon dyadic trade registers provided by the Stockholm International Peace Research Institute's (SIPRI) 'Arms Transfer Database.' SIPRI's supplier-recipient trade registers provide information concerning both the years in which specific conventional arms agreements were initially signed and include also the years during which deliveries on those agreements were made. In order to describe the quality 
of ongoing cooperation in any given year I focus specifically on the Aggregate Number of Contracts (ANC) in existence, where the ANC represents the sum of new and open contracts in a given year.

By focusing on the ANC rather than on data indicating the value of annual sales or the weapons typology, I anticipate that my indicator will more accurately reflect changes in the underlying political conditions which constitute the relationship. In particular, I expect that a climate of increasingly negative political relations would be reflected in few or no new contracts being signed as well as a general reduction, slow down, or cessation of deliveries on existing contracts. Conversely I expect that a positive political climate would be reflected by newly signed contracts as well as continuous deliveries of existing contracts.

In order to estimate the scaled level of cooperation indicated by the ANC in any given year I convert each score to a standard $\mathrm{Z}$ score (where $\mathrm{z}=(\mathrm{x}-\mu) / \sigma$ ) and then assign a corresponding ordinal value based upon the number of standard deviations each score is above or below the population mean (z-scores are a representation of how many standard deviations a given score is above or below the population mean). The population mean is calculated using the average annual ANC for the years of 1966 through 2010. I have chosen to use the post-World War II period of 1966 to 2010, rather than a shorter period more closely approximating the years of this study, because this expanded period is more likely to provide an accurate picture of long-term relations between Moscow and Tehran and therefore functions to mitigate reliability concerns 
associated with any particular year or set of years. The year 1966, in particular, is chosen as a starting point because this represents the first year in the post-WWII era in which Moscow and Tehran had formally entered into cooperative engagement in conventional weapons sales as indicated by SIPRI records. Table 2 provides the coding scheme for translating ANC z-scores into the 7-point scale of dyadic cooperation. Thus, for example, in order to code a given year with the rating of 'Strong Cooperation' the ANC z-score in a given year would need to be greater than or equal to 1 standard deviation above the population mean.

Table 2: Coding Scheme for transforming Aggregate Number of Defense Contracts (ANC) into 7point scale of cooperation.

\begin{tabular}{|c|c|}
\hline Level of Cooperation & Coding Scheme $\quad$ (ANC=Aggregate Number of Contracts) \\
\hline Strong Cooperation & ANC z-score is (> or =) 1.0 Standard Deviations Above Population Mean \\
\hline Moderate Cooperation & ANC z-score is (> or =) 0.5 Standard Deviations Above Population Mean \\
\hline Basic Cooperation & ANC z-score is (> or =) 0.1 Standard Deviations Above Population Mean \\
\hline Median Point & ANC z-score is $(<$ or $=)$ 0.1 Standard Deviations $\underline{\text { Above or Below the Population Mean }}$ \\
\hline Basic Non-Cooperation & ANC z-score is (> or =) 0.1 Standard Deviations Below Population Mean \\
\hline Moderate Non-Cooperation & ANC z-score is (> or =) 0.5 Standard Deviations Below Population Mean \\
\hline Strong Non-Cooperation & ANC z-score is (> or $=$ ) 1.0 Standard Deviations Below Population Mean \\
\hline
\end{tabular}

The value of this coding scheme can clearly be discerned by examining the data points in graphical format. Figure 3 (below) clearly conforms to the expectation that Russian-Iranian bilateral political cooperation was either low or non-existent throughout the 1970s and 1980s as a product of Cold War geopolitical alignments, the 1979 Iranian revolution and Soviet invasion of Afghanistan, as well as the Soviet Union's stated support for Iraq throughout the Iran-Iraq war. Similarly, Figure $\mathbf{3}$ also confirms the anticipated swelling of bilateral relations that occurred throughout much of the 1990s and 
early 2000s, but also notably recognizes the significant decline in cooperation during 1992 when both nations briefly supported adversarial factions in the Tajik civil war as well as the general downturn in relations that defines the period following 2006. A complete list of all annual observations may be found in the Appendix under Table A. 7.

Figure 3: Annual Cooperation in the Trade of Conventional Weapons (1966-2010).

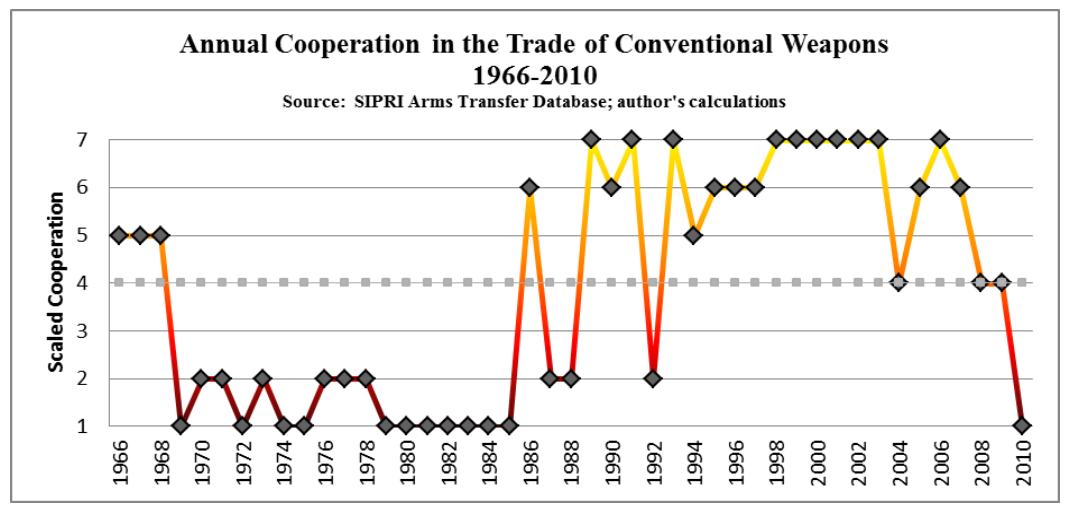

Measuring Inter-State Development Assistance: Annual cooperation in nuclear development (ACND)

State-sponsored development assistance is here operationalized as annual cooperation in nuclear development (ACND). Complicating any effort to measure ongoing nuclear cooperation between Russia and Iran is the fact that Moscow has often pursued a multi-vectored policy. While Russia has ultimately satisfied its initial commitments to the IRI regarding assistance in the development of civilian nuclear power (i.e.- construction of Bushehr nuclear power plant), the Kremlin and other elites 
have often pursued policies or actions which have simultaneously supported and undercut efforts to restrict the proliferation of highly-restricted technologies and materials essential to the development of a weaponized Iranian nuclear program; further complicating this scenario is the fact that policies/activities encouraging proliferation and non-proliferation occur at competing domestic and international levels.

In order to make sense of this often contradictory data I have created a system which allows me to numerically code each observable instance of cooperation or noncooperation in terms of a 7-point scale. Annual ACND scores are then determined by taking the average of all observable instances during a given year. Table 3 below represents the coding scheme used to document each instance of cooperation or noncooperation in nuclear development during a given year. Annual events are principally derived from Parker (2008), but have also been complemented by observations reported in Orlov \& Vinnikov (2005), Katzman (1998) and the Russian Federal Atomic Energy Agency. Although Parker does not offer a formal dataset of events pertaining to nuclear cooperation, his text is richly populated by descriptions of such events as well as the dates of their occurrence. Extracting event information from the text of Parker and the above-named supplementary sources, I have created a timeline of pertinent data that can be coded according to the coding scheme presented in Table 3 below. The event data used in this study is available upon request. 
Table 3: Coding scheme for nuclear cooperation event data.

\begin{tabular}{|c|c|c|}
\hline & Level of Cooperation & Conditions/Definitions \\
\hline 7 & Strong Cooperation & $\begin{array}{l}\text { Russian Federation provides Iran with critical diplomatic protection in international forums, } \\
\text { i.e.-actively blocking attempts by international community to address proliferation concerns } \\
\text { or impose sanctions regime. }\end{array}$ \\
\hline 6 & Moderate Cooperation & $\begin{array}{l}\text { Russian Federation establishes domestic policy, directives, legislation which could directly } \\
\text { destabilize Russian Federation's general commitment to non-proliferation (including } \\
\text { appointment of Ministers associated with proliferation risks). } \\
\text { - Can be increased by } 1 / 2 \text { point if Russia abstains from voting on measures which } \\
\text { could lead to international sanctions }\end{array}$ \\
\hline 5 & Basic Cooperation & $\begin{array}{l}\text { Russian Federation officially committed to aiding Iranian efforts to develop a distinctly } \\
\text { civilian nuclear program } \\
\text { - Can be increased by } 1 / 2 \text { point if high-ranking officials/elites are engaged or can be } \\
\text { reasonably suspected of involvement in activities increasing likelihood of } \\
\text { proliferation of restricted technologies to Iran }\end{array}$ \\
\hline 3 & Basic Non-Cooperation & $\begin{array}{l}\text { Russian Federation sponsoring efforts to delay development of Iranian civilian nuclear } \\
\text { program (e.g.-work slow- downs) } \\
\text { - Can be decreased by } 1 / 2 \text { point if high-ranking officials/elites are engaged in } \\
\text { activities decreasing likelihood of proliferation of restricted technologies to Iran. }\end{array}$ \\
\hline 2 & $\begin{array}{l}\text { Moderate } \\
\text { Non-Cooperation }\end{array}$ & $\begin{array}{l}\text { Russian Federation establishes domestic policy, directives, legislation which could directly } \\
\text { increase control over proliferation (including appointment of ministers associated with non- } \\
\text { proliferation activities) } \\
\text { - Can be decreased by } 1 / 2 \text { point if Russia abstains from voting on measures that } \\
\text { could lead to international sanctions. }\end{array}$ \\
\hline
\end{tabular}

The coding scheme represented in Table 3 makes three broad assumptions. In the first instance, the coding scheme assumes that higher levels of cooperation or noncooperation represent those efforts to either aid or restrict Iran in the development of a militarized nuclear program. Although Iranian officials have long-insisted that their government is not actively seeking a weaponized nuclear program, evidence of ongoing uranium enrichment activities, attempted acquisition of ballistic missile technology, and recent IAEA reports would suggest otherwise. In light of this, I assume that efforts aimed to aid the development of a distinctly militarized program represent a moderate 
level of collaboration insofar as they prioritize bilateral cooperation over adherence to multi-lateral agreements (such as the Nuclear Non-Proliferation Treaty) or international sanctions. Efforts deemed likely to support the development of a much-less controversial civilian nuclear program are assigned a lower magnitude cooperation score and are here represented as instances of basic cooperation. In terms of non-cooperation Russian efforts to restrict collaboration in Iran's development of civilian nuclear power is classified as an instance of basic non-cooperation, while efforts to limit or restrict the development of a weaponized program are treated as examples of moderate noncooperation.

The second key assumption made by this coding system lies in the fact that it evaluates instances of cooperation and non-cooperation in international venues such as the IAEA Board of Governors, the United Nations Security Council, and GoreChernomyrdin Commission as inherently more important than those events occurring internally (labeled as either strong cooperation or strong non-cooperation). As such, Russian efforts to block UNSC resolutions seeking to impair Iranian nuclear development are here represented as inherently more important instances of cooperation than even those domestic directives or initiatives which lead to concrete proliferation. While the actual proliferation of restricted technology may occur illegally or as a byproduct of lax enforcement policies, diplomatic support (or non-support) in key international forums represents an explicit intention on the part of the state leadership to support Iran in its quest for both civilian and military nuclear power. Conversely, efforts to support 
sanctions or public condemnations against Iran in international forums are deemed to be the highest levels of non-cooperation (strong non-cooperation) insofar as they represent the intentions of state leaders to side with western nations which have been generally opposed to Iranian nuclear aspirations. Based upon these criteria, Figure 4 (below) depicts annual cooperation in nuclear development (ACND) between Russia and Iran for the years $1985-2011$.

Figure 4: Annual Cooperation in Nuclear development (1966-2011).

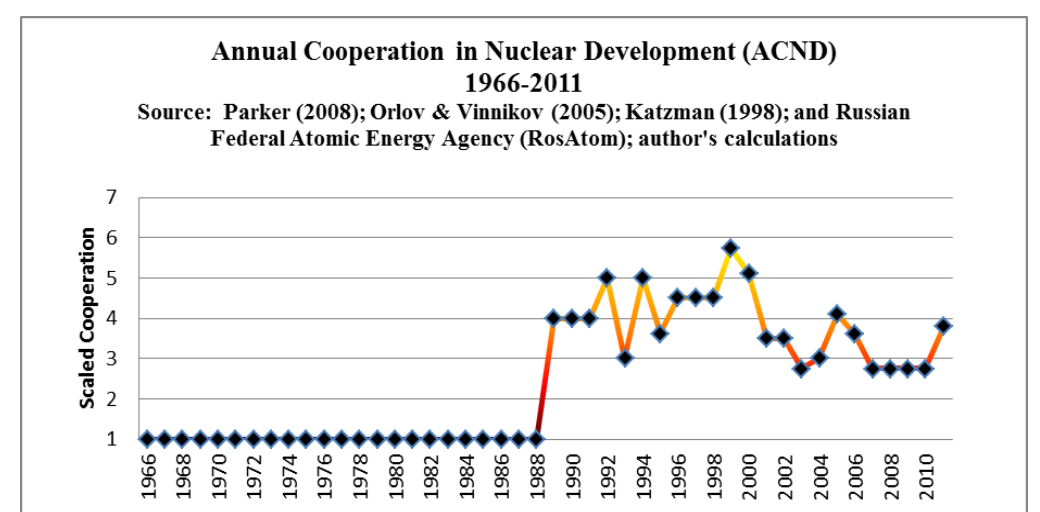

Measuring General Agreement on Territorial Divisions: Cooperation in Caspian Sea Delimitation $\underline{(\mathrm{CCSD})}$

In this section I operationalize 'General

Agreement on Territorial Divisions' as 'Cooperation in Caspian Sea Delimitation' (CCSD). In order to construct a measurement capable of expressing qualitative changes in bilateral cooperation on Caspian delimitation I begin by identifying 5 possible delimitation regimes that have been proposed or supported by the littoral nations since the collapse of the USSR. As discussed in this chapter, treaties signed in 1921 and 1940 between Moscow and Tehran provided the framework for long-standing delimitation agreement based upon a condominium principle where both the seabed and sea-surface were owned equally by Russia and Iran excepting a 10-mile sovereign, off-shore zone. 
Following the collapse of the Soviet Union in 1991 all newly independent nations were obliged to uphold existing delimitation treaties until a new joint regime could be established. Renewed international interest in the Caspian's abundant hydrocarbon resources during the 1990 s placed pressure on each of the littoral states to quickly identify a delimitation regime that would maximize their own particular share of maritime resources - a contingency which thus jeopardized the initial post-Soviet status quo. Although Russia and Iran would initially remain jointly committed to a condominium approach to resource utilization, by 1998 pressures within the Caspian would lead to the dramatic polarization of Russian-Iranian positions thereby fracturing the long-standing cooperative relationship. Although no new unanimous regime has yet been adopted, North Caspian nations today (Russia, Kazakhstan, and Azerbaijan) have already entered into formal bilateral treaties which are used to justify ongoing exploration and production (E\&P) activities in formal national sectors which are demarcated by a modified median line (MML). In contrast, both Iran and Turkmenistan today hold resolutely to the former Soviet-Iranian treaties emphasizing joint ownership and a condominium approach to resource extraction-claiming that no E\&P activities can be undertaken until all littoral nations have endorsed a unanimous delimitation regime.

Relying upon Mahmoud Ghafouri (Ghafouri, 2008), I identify 5 possible postSoviet delimitation regimes which can be scaled to represent distance intervals between Russia and Iran's preferred policy positions in any given year (see Table 4). Ghafouri's research is critical because it not only describes the variety of delimitation positions 
available, but also (informally) prioritizes the delimitation regimes according to each nation's preferences - scaling the five delimitation positions I can thus determine the distance interval between Russia and Iran's policy position in any given year. Distance intervals between policy positions during any given year are then compared against a 7point scaled indicator of cooperation to make a final determination regarding the nature of Cooperation in Caspian Sea Delimitation (CCSD) (See Table 5 at end of section).

Table 4: Scaled Caspian Sea delimitation positions of the five littoral nations.

\begin{tabular}{|c|c|c|}
\hline & $\begin{array}{c}\text { Scaled Caspian Delimitation } \\
\text { Positions }\end{array}$ & Notes: \\
\hline 1 & $\begin{array}{l}\text { Condominium approach to Caspian Sea resources } \\
\text { where equal joint utilization of all living and non- } \\
\text { living resources are permitted with exception of } 10 \\
\text { mile off-shore national zones }\end{array}$ & $\begin{array}{l}\text { Iran: 1940-1996; 1998-Present } \\
\text { Russia: 1940-1996 }\end{array}$ \\
\hline 2 & $\begin{array}{l}\text { Condominium approach to Caspian Sea resources } \\
\text { where equal joint utilization of all living and non- } \\
\text { living resources (both seabed and sea surface) are } \\
\text { permitted with exception of } 45 \text { mile off-shore national } \\
\text { zones. }\end{array}$ & $\begin{array}{l}\text { Iran: } 1996-1998 \\
\text { Russia: } 1996-1998\end{array}$ \\
\hline 3 & $\begin{array}{l}20 \% \text { Equal Share Division (ESD) of Caspian Sea } \\
\text { under a unified, legal regime for both seabed and } \\
\text { surface (a modified national sector approach) }\end{array}$ & $\begin{array}{l}\text { *Iran has advocated for this position but presently } \\
\text { insists that a delimitation regime based upon the } \\
\text { 1921/1940 Soviet-Iranian treaties should persist until } \\
\text { a new regime is established. }\end{array}$ \\
\hline 4 & $\begin{array}{l}\text { Modified Median Line (MML) division of Caspian } \\
\text { Seabed into sovereign national sectors with full state } \\
\text { sovereignty over both seabed and sea surface. }\end{array}$ & \\
\hline 5 & $\begin{array}{l}\text { Modified Median Line (MML) division of Caspian } \\
\text { Seabed into sovereign national sectors with joint } \\
\text { usage of sea surface for navigation. }\end{array}$ & Russia: 1998-Present \\
\hline
\end{tabular}

Table 4 (above) presents the five proposed delimitation regimes in a scaled format where lower places on the scale are reserved for joint ownership positions and a condominium approach to natural resource development. As indicated previously a condominium approach to resource development empowers all littoral nations with potential veto power over exploration and production activities and so incentivizes joint 
projects including all Caspian members as a way of defusing potential veto scenarios. Such a regime is thought especially favorable to Iran owing to the fact that hydrocarbon resource deposits in Iran's South Caspian location are less prevalent than in the North Caspian and located at greater depths thus raising the costs of production (Ghafouri, 2008, p. 89). The condominium approach subsequently provides Iran with greater access to Caspian resources and incentivizes all littoral nations to include Iran in E\&P opportunities despite ongoing international sanctions. Although both Russia and Iran adhered to position 1 for the greater portion of the $20^{\text {th }}$ century, by 1996 Russia, Iran, and Turkmenistan had proposed extending the 10 mile offshore zone to a 45 mile offshore zone (Ghafouri, p.87). Thus the year 1996 is treated as the high point of CCSD owing to the fact that both nations were diplomatically able to agree upon an alteration to the existing regime and were simultaneously capable of drumming up support from a neighboring littoral nation.

The other end of the scale is represented by variations on the modified median line position which divides up the Caspian Sea into unequal national sectors. Position 4 was initially endorsed by Azerbaijan and provided total state sovereignty over both the seabed and sea-surface (Ghafouri, p. 87). By 1998 Russia and Kazakhstan would informally agree to the national sector approach outlined in position 5 which although proposing national sovereignty over the seabed, left the sea-surface freely navigable - a position which Ghafouri notes is likely appealing to Russia because of the fact that it continues to ensure the free mobility of Russia's Caspian-based naval fleet across all sea 
waters (Ghafouri, 88-89). Azerbaijan would agree, informally, to the Russian-Kazakh position in January 2001 and would later sign a trilateral agreement with Russia and Kazakhstan to divide the North Caspian along these same lines in May of 2003 (Ghafouri, p. 88).

According to Ghafouri, position 5 should be the least palatable position to Iran because it not only significantly limits the IRI's ability to access resources outside of its own diminished national sector (as in the case of both positions 4 and 5) but moreover provides Iran with no legal buffer from Moscow's naval presence (Ghafouri, p. 89). Thus I infer that position 5 would be less favorable to Iran than position 4 where the seasurface is subject to national sovereignty. In response to the adoption of a national sector approach based upon a modified median line, Iran has suggested position 3 as a way to increase its share of Caspian maritime territory (Ghafouri, p. 89). Position 3 differs from the other national sector positions insofar as it proposes to provide each littoral nation with an equal $20 \%$ share of the seabed and sea-surface (Ghafouri, p. 89). While position 3 is a significant improvement over positions 4 and 5-which both would leave Iran with a diminished $11 \%$ share of the Caspian - there is clear reason to suspect that Iran would nevertheless still prefer joint ownership of the Caspian paired with a condominium approach to resource development as this would maximize Iran's ability to participate in lucrative exploration and production activities (Ghafouri, 89).

Table 5 below displays the coding scheme for the recognized distance intervals between delimitation positions and thereby establishes the annual level of cooperation in 
Caspian Sea Delimitation (CCSD) on a 7-point ordinal scale. Between 1940 and 1996 Russia and Iran shared the same approach to delimitation (position number 1) with a distance interval between positions of 0 (where $1-1=0$ ), thereby indicating a Moderate level of CCSD (level 6). Between 1996 and 1997 both nations moved simultaneously to adopt delimitation position 2 with a distance interval of 0 (where 2-2=0), gaining additional support for the new delimitation position from Turkmenistan thereby indicating a Strong level of cooperation (level 7). By 1998, however, the Russian Federation had dramatically altered its policy stance, adopting position 5 in tandem with Kazakhstan and later Azerbaijan. Moscow's move subsequently forced Iran to return to a preference for position 1 which calls for adherence to the delimitation regime outlined in the 1921 and 1940 Soviet-Iranian treaties until such time as all nations can unanimously agree on a new regime (Ghafouri, p. 89). The distance interval suggested by this change is therefore set at $4(5-1=4)$, indicating the greatest possible level of distance between established delimitation positions. The fact that Russia has persuaded two other nations to adopt this rival position further indicates an increasing degree of polarization in policy positions within the Caspian, a condition which suggests a level of Strong NonCooperation (level 1) since 1998. 
Table 5: Coding scheme for Cooperation in Caspian Sea delimitation based upon scaled position differences.

\begin{tabular}{|lll|}
\hline & Level of Cooperation & Conditions \\
\hline 7 & Strong Cooperation & $\begin{array}{l}\text { Agreement over delimitation (position difference=0) and dyad is capable of persuading } \\
\text { other states to join delimitation regime. }\end{array}$ \\
\hline 6 & Moderate Cooperation & Agreement over delimitation (position difference=0) \\
\hline 4 & Basic Cooperation & General agreement over delimitation (position difference=1) \\
\hline 3 & Basic Non-Cooperation & $\begin{array}{l}\text { General disagreement over delimitation (position difference=3) marginal likelihood of } \\
\text { accommodation }\end{array}$ \\
\hline 2 & Moderate Non-Cooperation & Disagreement over delimitation (position difference $=4$ ) low likelihood of accommodation \\
\hline 1 & Strong Non-Cooperation & $\begin{array}{l}\text { Disagreement over delimitation (position difference=4) one member of dyad has joined } \\
\text { alternate delimitation regime with other state actors }\end{array}$ \\
\hline
\end{tabular}

Figure 5: Annual Cooperation in Caspian Sea delimitation (1966-2010).

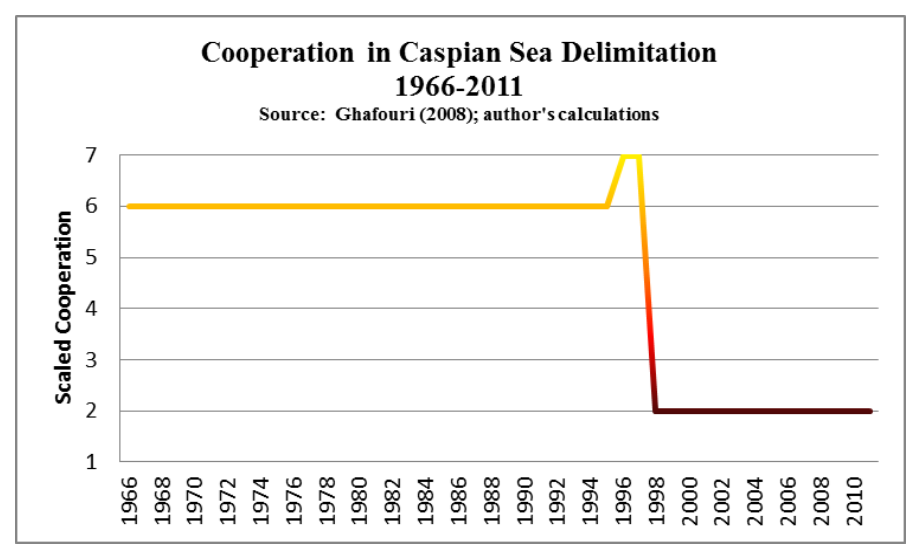

The indicator of annual

CCSD scores (Figure 5) quite clearly represents the narrative of Caspian cooperation discussed throughout this chapter and further demonstrates

the importance of taking a multi-dimensional approach to measuring political affinity. Although cooperation in the trade of conventional weapons and nuclear development had continued roughly until 2006, it is clear that bilateral relations were already subject to a significant level of strain as early as 1998 when Russia began to adopt an increasingly adversarial position in matters of Caspian delimitation. Thus while it is fair to say that the late 1990s and early 2000s may have represented an unprecedented level of defense and development cooperation between Russia and Iran, it is clearly also the case that overall affinity was simultaneously being moderated by changes in Caspian geopolitics. 
Such cases remind us that political relations between two nations are not without their fair share of contradictions and that the quality of relations in any given year is best represented by a summary of all important political developments. As such we can be increasingly assured that a multi-dimensional measurement of political affinity-as presented in the following section-represents our best effort at approximating the complex reality of Russian-Iranian relations.

\section{$\underline{\text { Russian Iranian General Political Affinity (GPA): Revealing a dependent variable }}$}

Figure 6 (below) represents the annual level of General Political Affinity (GPA) between Russia and Iran for the years 1966-2011. Annual scores represent the sum of all three underlying variables (Trade in Conventional Weapons; Nuclear Development; and Caspian Sea Delimitation) and are expressed in terms of a 21-point scale of cooperation. The decision to sum all three scores is based upon the desire to express the greatest range of variance in order to maximize the indicator's overall utility in cases of analysis and testing. Score tables for the period of this study 1987-2011 are located in the Appendix (see Table A. 7) and provide annual data points for each sub-component of GPA. It should be noted that 2011 data for the Trade in Conventional Weapons (TCW) is not yet available; in order to account for this missing period of data, I simply apply the 2010 TCW score to year 2011. 
It will be noted that the summed indicator of GPA presented in Figure 6 closely corresponds to the historical discussion presented during Chapter II. The measurement of GPA presented here not only confirms that bilateral relations between both nations had reached their highest point during the 1990s but it also clearly demonstrates how such cooperation began to progressively diminish starting in the late 1990s. The close degree of correspondence to the preceding discussion should serve to increase efficacy in this indicator's sub-components as well as in the model's overall utility.

In terms of this model's advantages, GPA's 21-point scale not only enables researchers to differentiate between three broad categories of cooperation (high, moderate, and low), but more specifically it can be used to illustrate minor fluctuations operating within each category or period of time. Thus while the depiction of GPA here clearly mirrors the broad changes in cooperation highlighted in the preceding discussion, it also recreates the turbulence that has defined Russian-Iranian cooperation on a year by year basis. In this capacity, GPA proves itself an essential tool for representing the ongoing 'crisis' of cooperation that has come to define bilateral relations in the postSoviet era

In more generic terms, Figure 6 reminds us that while moderate levels of cooperation between Moscow and Tehran may tend to predominate, the potential to broaden cooperation is also invariably inherent. If periods of moderate-cooperation serve to remind us of an abiding mixed utility for ongoing relations, periods of strongcooperation (as evident during the 1990s) also suggest that this unique political dyad 
maintains the ability to overcome its mutual apprehensions and to deepen political collusion when necessary.

Figure 6: Russian-Iranian General Political Affinity 1966-2011.

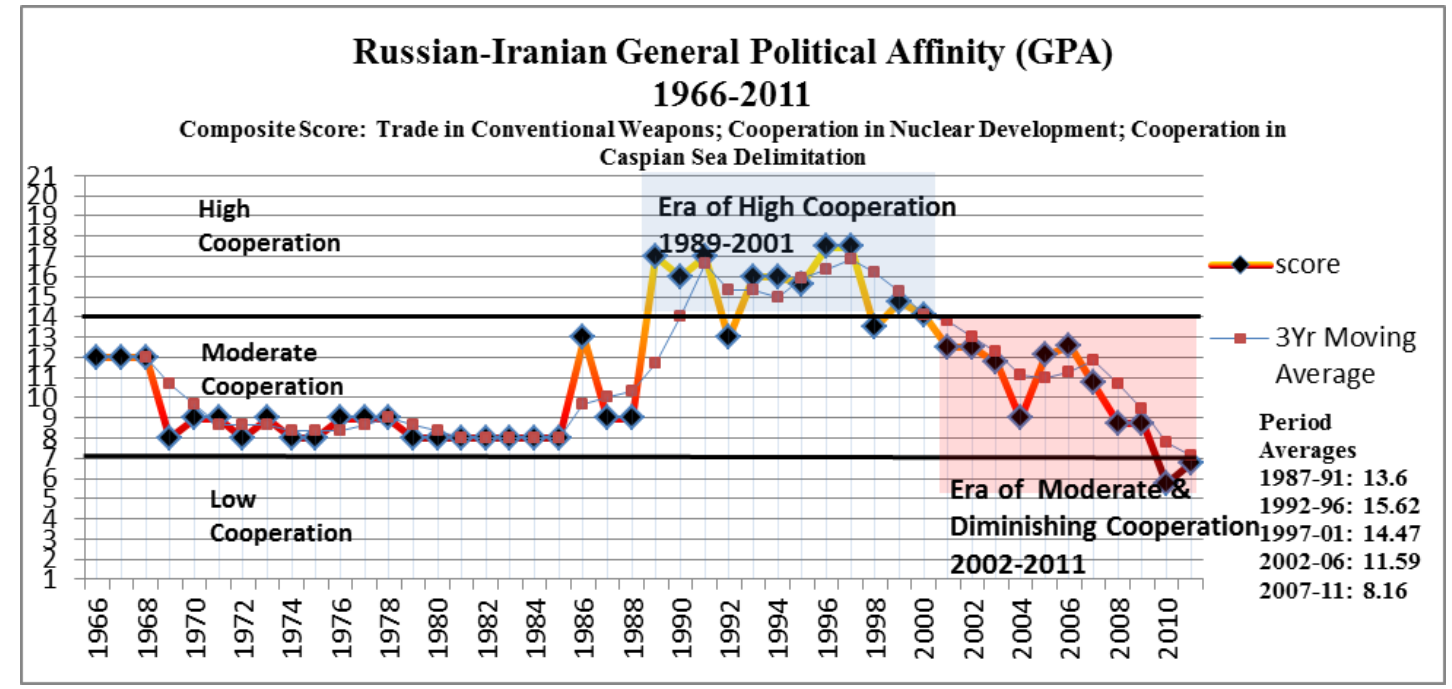

\section{Evaluating the Utility of General Political Affinity}

While the indicator of General Political Affinity (GPA) is well-grounded in the tradition of literature detailing Russian-Iranian relations, there are simple steps that can be taken still in order to improve overall efficacy in it, and to dispel uncertainties about its viability as an indicator of bilateral political affinity. In this section I focus specifically upon resolving two key issues with GPA.

In the first instance, I evaluate whether or not GPA should reasonably be comprised solely of political sub-components or whether it should also include some component of economic data. Testing the data, I determine that an additional economic 
sub-component would not greatly improve the explanatory power of GPA and so determine to preserve GPA as it has been presented during this chapter. In the second instance I evaluate whether or not GPA does, in fact, measure what it specifically purports to, i.e.- bilateral political affinity of Moscow and Tehran. Testing GPA for both discriminant and convergent validity, I determine that GPA is, in fact, a strong predictor of bilateral political affinity between Moscow and Tehran.

\section{Test 1: Evaluating the Utility of Adding an Economic Sub-Component}

In this section I seek to evaluate whether or not GPA could be greatly improved by adding an economic sub-component to its underlying set of politically-oriented variables. While principle component analysis may be used to determine those underlying factors which should reasonably be included in a composite variable, the low number of observations precludes any robust statistical analysis, and encourages me to evaluate the utility of its sub-components using an alternate methodology.

By correlating GPA with an overtly economic variable it is possible to determine whether or not bilateral relations are substantively premised upon economic concerns. In the event that GPA correlates highly with the economic data it would be natural to assume that economic considerations are a principle part of the dyad's ongoing interactions with one another, and that any measure of GPA should include some attention to economic data. In the event that GPA does not strongly correlate with the economic variable, it would be alternately safe to conclude that bilateral relations are 
predominantly grounded in overtly political considerations, and that the sub-components of GPA — as presented in this chapter—should remain unchanged.

In order to measure the changing utility of the dyad's economic partnership to both Russia and Iran (EU), I express the value of each nation's exports to the other as a percentage of all of its global exports during a given year. The utility of the economic partnership for each nation is therefore represented as:

$$
\mathrm{EU}=[(\text { Ex_nation/Ex_world }) * 100]
$$

Where EU=economic utility of partnership to a given nation; Ex_nation=the value of exports to the partner nation during a given year; and Ex_world=the value of all national exports during a given year.

Data for these variables is derived from the International Monetary Fund's "Direction of Trade Statistics" database which includes constant export data for the years 1985-2011 for the USSR/Russia, and 1988-2011 for Iran. Data between 1985 and 1991 corresponds to exports between the U.S.S.R. and Iran, while data between 1992 and 2011 corresponds to exports between the Russian Federation and Iran. Annual data for the both nation's economic utility for partnership can be found in the Appendix Tables A. 2 and A. 3.

In order to determine whether or not there is any meaningful level of association between GPA and both Russia and Iran's economic utility for partnership (EU) I utilize the Spearman's Rank Correlation method. The Spearman's method proves useful here because unlike the more-traditional Pearson's method, it does not require both variables 
to be normally distributed; in particular, the variable of GPA is not normally distributed and so violates one of the fundamental conditions of the Pearson's approach. I define an association between variables as 'significant' whenever the correlation coefficient is both greater than $+/-0.4$, and where the corresponding p-value is less than 0.05 .

\begin{tabular}{|llll|}
\hline Variable & rho coefficient & 2-tailed p-value & Significance \\
\hline EU_USSR/Russian Federation & -0.3444 & 0.07856 & $\mathrm{P}>0.05$ \\
EU_Iran & 0.1198 & 0.57713 & $\mathrm{P}>0.05$ \\
\hline
\end{tabular}

Table 6. Correlation matrix for analysis of GPA and Economic Utility for Partnership. Calculations performed online using: Wessa P., (2012), Spearman Rank Correlation (v1.0.1) in Free Statistics Software (v1.1.23-r7), Office for Research Development and Education, URL http://www.wessa.net/rwasp_spearman.wasp/

Results presented in Table 6 (above) clearly indicate that GPA is not significantly associated with either nation's economic utility for partnership (EU). In both cases the correlation coefficient for both variables is below the threshold of $+/-0.4$ and the value of $p$ is greater than .05 . Based upon these findings I can conclude that political relations between Moscow and Tehran (as presented in GPA) are not likely to be a function of either nation's expected utility for economic partnership and so conclude that relations may adequately be represented by the distinctly political sub-components of GPA.

Test 2: Testing for Discriminant and Convergent Validity of GPA

In this section I seek to evaluate whether or not GPA can reasonably be found to measure the concept of bilateral political affinity between Moscow and Tehran which it purports to. Successfully testing for both discriminant and convergent validity enables 
this study to reasonably claim: 1) that GPA is not measuring some other concept besides bilateral political affinity; and 2) that GPA is an accurate, yet unique, measurement of bilateral political affinity. Taken together this round of tests should substantially increase overall efficacy in GPA's ability to meaningfully depict bilateral political affinity between Moscow and Tehran.

\section{Test of Discriminant Validity}

In order to determine whether or not GPA may be measuring some concept other than bilateral political affinity I have formulated two alternate concepts which GPA could be claimed to represent. With the Islamic Republic of Iran listed by the $I M F$ as an "emerging \& developing economy," it is possible to assume that changes in GPA do not reflect merely bilateral political relations but rather that they represent the broadly changing quality of USSR/Russian relations to all countries of this same socio-political and economic class - what might be referred to alternately as the Global South. In this manner, periods of intense cooperation represented by GPA could be taken to indicate a growing policy convergence between Moscow and the world's less developed countries. Alternately, periods of diminished cooperation may represent a move away from the Global South towards a state of heightened relations with the world's advanced economies, i.e.-the Global North.

In order to determine whether or not this may, in fact, be the case, I correlate GPA with an indicator representing Russia's relations to the Global South (RUS_GS). To 
operationalize this concept I simply estimate the annual percentage value of the USSR/Russian Federation global exports that are derived from trade with economies of the Global South. Russia's relations to the Global South may therefore be represented as:

$$
\text { RUS_GS=[Ex_GS/Ex_world)*100] }
$$

Where RUS_GS=Russian relations to the Global South; Ex_GS=Value of Russian exports to the Global South (IMF's 'emerging \& developing economies'); and Ex_world=the value of all Russian global exports during a given year.

Data for this indicator is derived from the International Monetary Fund's "Direction of Trade Statistics" database, which provides uninterrupted export data between the USSR/Russia and all countries classified as Emerging and Developing Economies for the years 1981-2011. As in the previous round of testing, data prior to 1992 is culled from USSR export statistics and data post-1992 is taken from Russian Federation figures. Data for RUS_GS may be found in the Appendix, Figure A. 4.

In the second instance, I determine to ask the question of whether or not GPA may, in fact, be simply mirroring the coverage of media reports dedicated to the discussion of bilateral relations rather than the subtleties of actual bilateral political relations. Insofar as GPA's origins lie firmly in existing literature on the discussion of bilateral relations, and more importantly because the data sources for each of the individual sub-components of GPA are highly likely to have been based in media reporting, it is possible to assume that GPA is simply a reflection of media coverage and not bilateral political affinity. Data for MC, may be found in the Appendix, Table A. 5 . 
To evaluate whether or not GPA is, in fact, a reflection of media coverage (MC), I correlate GPA with an indicator which represents the number of published articles directly discussing Russian-Iranian relations (MC). To locate this data, I have performed a search of 'Major World Publications' listed in Lexis Nexus for any articles which reference Russian-Iranian relations in their headline between January $1^{\text {st }}$ and December $31^{\text {st }}$ of each calendar year between 1979 and 2011 (there are no entries prior to 1979). The specific search term for this query is: HEADLINE (Russia and Iran) AND relations.

The methodology used for this round of testing mirrors the regime established in the previous section, relying upon the Spearman's Rank Order of correlation. As Table 7 (below) clearly demonstrates, neither variable correlates significantly with GPA. In both cases, RUS_GS and MC fail to correlate with GPA at a level above +/- 0.4 and both fail to produce p-values lower than .05 . These results provide direct confirmation that GPA is not likely to be measuring some alternate concept; given this data, I therefore conclude that GPA is more likely to be measuring specifically what it purports tobilateral political affinity between both Moscow and Tehran.

\begin{tabular}{|llll|}
\hline Variable & rho coefficient & 2-tailed p-value & Significance \\
\hline RUS_GS & 0.008091478 & 0.965541544 & $\mathrm{P}>0.05$ \\
MC & -0.017321356 & 0.923779542 & $\mathrm{P}>0.05$ \\
\hline
\end{tabular}

Table 7: Correlation matrix for test of discriminant validity. Calculations performed online using: Wessa P., (2012), Spearman Rank Correlation (v1.0.1) in Free Statistics Software (v1.1.23-r7), Office for Research Development and Education, URL http://www.wessa.net/rwasp_spearman.wasp/ 


\section{Test of Convergent Validity}

Any test for discriminant validity must, however, be a supplemented by a simultaneous effort to demonstrate that GPA is, in fact, generally functioning as a solid indicator of bilateral political affinity in a direct manner. In a test for convergent validity, the researcher is tasked with locating an alternate variable that could also be claimed to directly represent the concept being measured, in this case bilateral political affinity. In those instances where a strong positive correlation between the two variables can be obtained, it can be assumed that the target variable is, in fact, accurately representing the concept in question. If, however, correlation is found to be insignificant, then it may conversely be assumed that the target indicator is unlikely to be a good predictor of the concept in question; thus both tests of discriminant and convergent validity work together to demonstrate the likelihood that the target indicator models what it purports to.

In this section I attempt to determine whether there is any meaningful correlation between GPA and the similarity of Russian-Iranian security alliance portfolios. The usage of security alliance portfolios to measure the affinity of governments dates back to Bruce Bueno de Mesquita's (1975) introduction of the Tau-b measurement of alliance portfolio similarity. This indicator was subsequently employed by Organski \& Kugler (1980) and Kim (1991) in Power Transition research as a means for evaluating the likely affinity between individual governments and the state leader of the international system. In 1999 Signorino \& Ritter presented what they describe as an improved method for evaluating the similarity of alliance portfolios. Known widely as the $S$-calculation of 
alliance portfolio data, this measurement has become the sine qua non for measuring this relationship and has been made popularly available by Bennett \& Stam's Expected Utility and Data Management Program (EUGene). EUGene alliance portfolio data is derived from the Correlates of War (COW) version 3.0 alliance dataset which was made available in 2002 .

As in previous sections, I correlate GPA with $S$ utilizing the Spearman's method, relying upon the same criteria previously established for determining significance. Data for $S$ has been culled from EUGene for the years 1966 to 2000; EUGene does not provide alliance portfolio data for years after 2000. The specific calculation of alliance portfolio data utilized in this series of tests represents regional, weighted data-wherein state alliance portfolios are limited to states within "the relevant region for the dyad" and where $S$ scores are further weighted by taking into account state capabilities data obtained from the Correlates of War CINC dataset (Bennett \& Stam, 2007, p. 38). Data for $S$ may be found in Appendix, Table A. 6.

\begin{tabular}{|llll|} 
Variable & rho coefficient & 2-tailed p-value & Significance \\
\hline $\begin{array}{l}\text { S-Calculation of Alliance Portfolio } \\
\text { Similarity }\end{array}$ & 0.410988921 & 0.014182619 & $\mathrm{P}<0.05$ \\
\hline
\end{tabular}

Table 8: Correlation matrix for test of convergent validity. Calculations performed online using: Wessa P., (2012), Spearman Rank Correlation (v1.0.1) in Free Statistics Software (v1.1.23-r7), Office for Research Development and Education, URL http://www.wessa.net/rwasp_spearman.wasp/

Table 8 (above) demonstrates clearly that the correlation between GPA and S is significant and in the expected direction. With a correlation coefficient above 0.4 and $\mathrm{p}<0.05$, we can safely assume that GPA does, in fact, provide an expedient measurement 
of bilateral political affinity. Equally important is the finding that correspondence between both variables is not overly robust. In the event that both variables correlated perfectly with one another, we would be required to accept the premise that $S$-as an existing measure of political affinity—was equally well tasked for evaluating the relation of governments thereby calling into question the necessity of an alternate methodology as has been presented by GPA. In contrast, the lower-yet significant-level of correspondence clearly demonstrates that GPA is measuring bilateral political affinity and that it also stands as a unique alternative means of measuring relations between Moscow \& Tehran. Given this indicator's strong foundation in literary traditions detailing Russian-Iranian relations, there is every reason to suspect that GPA likely outperforms the generic indicator of $S$ in accurately modeling Russian-Iranian relations.

In consideration of the above testing regime, I find that GPA maintains a high degree of utility for adequately representing Russian-Iranian bilateral political relations. In the first instance it is apparent that the three distinctly political sub-components should not be further augmented by the addition of an economic variable. As demonstrated, political cooperation is not significantly associated with either nation's estimation of the value of economic partnership; in other words, partnership of these two nations does not depend upon perceptions of overall economic utility. In the second instance, validity testing indicates that GPA is neither reflective of some concept other than bilateral political affinity, and that it can reasonably serve as an unprecedented model of the status of political relations at any given time. In light of these findings, this study offers GPA 
as an innovative and accurate means for monitoring changes in Russian-Iranian political relations over time. 


\section{Chapter IV}

Conclusion

\section{$\underline{\text { Introduction }}$}

In the Crisis of Cooperation, I have attempted to critically evaluate one of the most prominent and controversial political relationships of the post-Cold War era. Although relations between Moscow and Tehran had often been highly adversarial during

the $19^{\text {th }}$ and $20^{\text {th }}$ centuries, high levels of cooperation exhibited in the early post-Cold War era have forced scholars, and policy-makers alike, to re-evaluate the nature of this bilateral relationship, causing them, in turn, to examine those myriad factors deemed to be principal to cooperation. But the dearth of critical scholarship on the subject of Russian-Iranian relations has not helped us to confidently answer some of our most basic questions about the nature of this relationship or where, in fact, the partnership might be headed in the coming years. Rather than subjecting this political partnership to empirical analysis, speculation and historical recitation have, to date, only further muddied the waters of political inquiry. By redirecting the analysis of Russian-Iranian relations into a science-based forum, this study has attempted to aggregate, explain, and empirically evaluate those factors deemed pertinent to bilateral cooperation.

By translating complex historical interactions into a user-friendly dependent variable referred to as General Political Affinity, this study has sought to bring increasing clarity and consensus to the study of Moscow \& Tehran's political partnership in a manner that is unprecedented in the existing literary tradition. The measured expression 
of political affinity along a 21-point scale has not only created a new platform for meaningful dialogue among students of Russian-Iranian relations but, perhaps more importantly, it also paves the way for future empirical research into those factors and forces that may be responsible for driving changes in cooperation between Moscow and Tehran over time.

While establishing an effective dependent variable is essential to progress in empirical research, it is only the first of many hurdles to be attempted in order to truly understand the complex nature of political relations in this most-important partnership. Developing a complete understanding of the perennial factors and forces that drive changes in cooperation will require scholars and analysts alike to revisit the considerable scope of literature on the subject in order to develop empirically falsifiable hypotheses about what factors are, and are not, salient to cooperation. By redirecting the record of literary discussion away from speculative, individual accounts into a science-based dialogue, not only will we be empowered to make articulate and defensible claims about the nature of relations, but so too will those claims ultimately enhance our understanding of international affairs.

In some manner this process has already begun. By evaluating GPA as a function of three substantive underlying issue dimensions (trade in conventional weapons, cooperation in nuclear development, and the status of agreement on Caspian Sea delimitation) this has suggested that bilateral relations are, generically or universally, a function of three perennial factors: cooperation in matters of defense; state-sponsored 
development assistance; and territorial agreement. While such abstractions are ultimately only a hypothesis about the ingredients of political affinity, such a hypothesis functions as a primer for understanding political relationships across the globe that can be tested and evaluated by the community of scholars and policy professionals. Thus while this study has taken explicit steps to critically define the nature of Russian-Iranian relations, one of its most important contributions lies in its development of an efficient blueprint for understanding political partnerships between nations everywhere. In this manner, subsequent investigations into the factors and forces deemed responsible for driving changes in Russian-Iranian affinity will only further contribute to our generic understanding of what motivates international outcomes. Such information remains important not only for the discipline of political science, but so also for the community of policy professionals which are equally committed to explaining and predicting international outcomes. 


\section{References}

Bennett, D. S., \& Stam, A. (2000). EUGene: A Conceptual Manual. International Interactions 26:179-204.

Bueno de Mesquita, B. (1975). "Measuring Systemic Polarity," The Journal of Conflict Resolution 19(2): 187-216.

Bueno de Mesquita, B. (1981). The war trap. New Haven: Yale University Press.

Bugajski, J. (2008). Expanding Eurasia: Russia's European ambitions. Washington, D.C.: CSIS Press.

Faulconbridge, G., \& Gutterman, S. (2011, November 11). Russia eyes building more nuclear power plants for Iran," Reuters. Retrieved from http://in.reuters.com/article/2011/11/10/idINIndia-60456220111110

Foglizzo, J. (2008). Russia's new energy strategy seems a lot like its old one. New York Times. Retrieved from:

http://www.nytimes.com/2008/03/30/business/worldbusiness/30ihtrnrgruss.1.11526942.html

Freedman, R. O. (1997). Russia and Iran: A tactical alliance. SAIS Review 17(2): 93-109.

Freedman, R.O. (2001). Russian policy toward the Middle East: The Yeltsin legacy and the Putin challenge. Middle East Journal 55(1): 58-90.

Gazprom (2012). Available online at: www.gazprom.com/production/transportation

Ghafouri, M. (2008). The Caspian Sea: Rivalry and cooperation. Middle East Policy 25(2): 81-96.

Gibler, D.M. (2009). International Military Alliances from 1648-2008. Washington D.C.: Congressional Quarterly Press.

Gibler, D. M., \& Sarkees, M. (2002). Coding Manual for v3.0 of the Correlates of War Formal Interstate Alliance Data set, 1816-2000. Typescript. For contribution to EUGene software program and calculations.

Gutterman, S. (2011, November 9). Russia opposes new Iran sanctions over IAEA report. Reuters. Retrieved from http://uk.reuters.com/article/2011/11/09/usnuclear-iran-russia-idUKTRE7A857620111109

Hiro, D. (1986, December 21). Tehran reaffirms Moscow ties while playing off the superpowers, Los Angeles Times. Retrieved from http://articles.latimes.com/1986-12-21/opinion/op-4162_1_khomeini

Imam Khomeini Official Website (2012). Iran-Russia relations: From Imam Khomeini's letter to the collapse of the Soviet Union. Available online at: http://www.imamkhomeini.ir/portal/page/portal/EN/news/Detail.html?id=4375\& Title=From-Imam-Khomeini\%E2\%80\%99s-letter-to-the-collapse-of-the-SovietUnion.

International Monetary Fund (2012, October). "Direction of Trade Statistics" database. Available online at: www.imf.org 
Katz, M. N. (2006). Putin, Ahmadinejad and the Iranian nuclear crisis. Journal Compilation, Middle East Policy Council. Retrieved from http://digilib.gmu.edu/dspace/bitstream/1920/3020/4/Putin\%20Ahmadinejad\%20a nd\%20Iranian\%20Nuclear\%20Crisis.pdf

Katz, M. N. (2010). Russia's greater Middle East policy: Securing economic interests, courting Islam, Russia/NIS Center. Retrieved from www.ifri.org/downloads/ifrirussiamiddleeastkatzengapril2010.pdf

Katzman, K. (1998). Iran: arms and technology acquisitions. Congressional Research Service report for Congress. Retrieved from http://digital.library.unt.edu/ark:/67531/metacrs824/m1/1/high_res_d/97474_1998Jun22.pdf

Katzman, K. (2007). The Iran Sanctions Act (ISA). Congressional Research Service report for Congress. Retrieved from http://www.fas.org/sgp/crs/row/RS20871.pdf;

Kemp, G. (2000). U.S.-Iranian relations. In R. Ebel, \& R. Menon (Eds.), Energy and Conflict in Central Asia and the Caucasus (pp. 145-162). Lanham, Maryland: Rowman \& Littlefield Publishers, Inc.

Kempster, N. (1989, June 24). U.S. criticizes Soviet offer to aid Iranian forces. Los Angeles Times. Retrieved from http://articles.latimes.com/1989-06-24/news/mn1864_1_soviet-promise-aid-iran-forces-soviet-union

Kessler, G., \& Richburg, K. B. (2010, June 12). Russia halts sale of air defense missiles to Iran. The Washington Post online. Retrieved from http://www.washingtonpost.com/wpdyn/content/article/2010/06/11/AR20100611 20100.html

Kim, W. (1991). "Alliance Transitions and Great Power War," American Journal of Political Science 35(4): 833-850.

Kwon, G. (2006). The budgetary impact of oil prices in Russia, 2003. International Monetary Fund. Retrieved from http://www.imf.org//external/country/rus/rr/2003/pdf/080103.pdf

MacDougall, J. (1997). Russian policy in the Transcaucasian 'near abroad:' The case of Azerbaijan. Demokratizatsiya: The Journal of Post-Soviet Democratization 5(1): 89-104.

Makarova, N., \& Kevorkova, N. (2010, August 20). Bushehr nuclear saga enters final chapter. Russia Today online. Retrieved from https://rt.com/politics/bushehr-plant-launch-iran/

Mamedova, N. M. (2009, July 20). Russia ii. Iranian-Soviet relations (1917-1991). Encyclopaedia Iranica, Online edition. Retrieved from http://www.iranicaonline.org/articles/russia-ii-iranian-soviet-relations-1917-1991

Milani, A. (2007). Russia and Iran: An anti-western alliance? Current History (October): 328-332.

Missile Technology Control Regime Official Website. Available at: 
http://www.mtcr.info/english/index.html

Olcott, M. B. (2004). International gas trade in Central Asia: Turkmenistan, Iran, Russia and Afghanistan. Working Paper prepared jointly for Stanford University's Program on Energy and Sustainable Development and the James A. Baker III Institute for Public Policy of Rice University. Retrieved from http://iisdb.stanford.edu/pubs/20605/Turkmenistan_final.pdf

Organski, A.F.K. \& Kugler, J. (1980). The War Ledger. Chicago: The University of Chicago Press.

Orlov, V. A., and Vinnikov, A. (2005). The great guessing game: Russia and the Iranian nuclear issue. The Washington Quarterly 28(2): 49-66.

Parker, J. W. (2008). Persian dreams: Moscow and Tehran since the fall of the Shah. Washington, D.C.: Potomac Books, Inc.

Power, J. (1993, August 6). A New Front for Islamic Militancy. The Baltimore Sun. Retrieved from http://articles.baltimoresun.com/1993-0806/news/1993218125_1_islamic-tajikistan-poland

Radio Free Europe/Radio Liberty (2008, January 28). Russia completes nuclear fuel deliveries to Iran. Retrieved from http://www.rferl.org/content/article/1144039.html

Rakel, E. P. (2007). Iranian foreign policy since the Islamic revolution, 1979-2006. PGDT 6:159-187. Retrieved from http://all-iran.info/lse/wpcontent/uploads/2009/03/26210546-ir_foreign_policy_1997-2006.pdf

Rakel, E. P. (2009). The political elite in the Islamic Republic of Iran: From Khomeini to Ahmadinejad. Comparative Studies of South Asia, Africa and the Middle East 29(1): 105-125.

Reuters (1986, November 30). Soviet arms sales to Iran reported. Reuters. Retrieved from http://articles.latimes.com/1986-11-30/news/mn-534_1_soviets

Rubinstein, A. Z. (1982). Soviet policy toward Turkey, Iran, and Afghanistan: The Dynamics of influence. New York, N.Y.: Praeger.

Saberi, R. (2006, August 1). Analysis: Iran's nuclear fuel debate. BBC News. Retrieved from http://news.bbc.co.uk/2/hi/middle_east/5235732.stm

Signorino, C. S., and Ritter, J. M. (1999). Tau-b or not Tau-b: Measuring the similarity of foreign policy positions. International Studies Quarterly 43(1): 115-144.

Singer, J. D. (1987). Reconstructing the Correlates of War Dataset on Material Capabilities of States, 1816-1985. International Interactions, 14: 115-32. For contribution to EUGene software program and calculations.

Singer, J. D., Bremer, S., \& Stuckey, J. (1972). Capability Distribution, Uncertainty, and Major Power War, 1820-1965. In Bruce Russett, ed., Peace, War and Numbers. Beverly Hills: Sage. For contribution to EUGene software program and calculations.

Singer, J.D., \& Small, M. (1966). "Formal Alliances, 1815-1939," Journal of Peace 
Research (3): 1-31. For contribution to EUGene software program and calculations.

Small, M., \& Singer, J.D., (1969). "Formal Alliances, 1815-1965: An extension of the basic data," Journal of Peace Research (6): 257-282. For contribution to EUGene software program and calculations.

Stockholm International Peace Research Institute (SIPRI). Arms Transfer Database. SIPRI. Available online at http://www.sipri.org/databases/armstransfers/armstransfers

Tammen, R. L., Kugler, J., Lemke, D., Stam III, A. C., Abdollahian, M., Alsharabati, C., et al. (2000). Power Transitions: Strategies for the $21^{\text {st }}$ Century. New York: Chatham House Publishers.

Trenin, D. V., Malashenko, A. V., \& Lieven, A. (2004). Russia's restless frontier: The Chechnya factor in post-Soviet Russia. Washington D.C.: Carnegie Endowment for International Peace.

U.S. Energy Information Administration (March 3, 2009). World Proved Reserves of Oil and Natural Gas. See figures reported from Oil and Gas Journal (January $1^{\text {st }}$, 2009) Available at: http://www.eia.gov/emeu/international/reserves.html

U.S. Energy Information Administration (2012). Iran Country Profile. USEIA. Retrieved from http://www.eia.gov/emeu/cabs/Iran/pdf.pdf

United Press International (UPI) (2011, August 30). Iran sues Russia over missing missiles. UPI. Retrieved from http://www.upi.com/Business_News/SecurityIndustry/2011/08/30/Iran-sues-Russia-over-missing-missiles/UPI98241314725856/

United Nations Bibliographic Information System (UNBISNET) (2012). Hosted online by the Dag Hammarskjold Library Available at http://www.un.org/Depts/dhl/

Wassenar Arrangment Official Website. Available at: www.wassenar.org

Wehling, F. (1999). Russian Nuclear and Missile Exports Iran. The Nonproliferation Review (Winter): 134-143.

Werner, S. (2000). The Effects of Political Similarity on the Onset of Militarized Disputes, 1816-1985. Political Research Quarterly 53(2): 343-374.

Wessa, P. (2012), Free Statistics Software, Office for Research Development and Education, version 1.1.23-r7, URL http://www.wessa.net/rwasp_spearman.wasp/ 


\section{Appendix}

Table A. 1: Gazprom shareholding controlled by the Russian Federation.

Source: Gazprom corporate website.

\begin{tabular}{|r|r|}
\hline & $\begin{array}{l}\text { Gazprom shareholding } \\
\text { controlled by the } \\
\text { Russian Federation }\end{array}$ \\
\hline $\mathbf{1 9 9 6}$ & 40.87 \\
\hline $\mathbf{1 9 9 7}$ & 40.87 \\
\hline $\mathbf{1 9 9 8}$ & 38.37 \\
\hline $\mathbf{1 9 9 9}$ & 38.37 \\
\hline $\mathbf{2 0 0 0}$ & 38.37 \\
\hline $\mathbf{2 0 0 1}$ & 38.37 \\
\hline $\mathbf{2 0 0 2}$ & 38.37 \\
\hline $\mathbf{2 0 0 3}$ & 38.37 \\
\hline $\mathbf{2 0 0 4}$ & 38.37 \\
\hline $\mathbf{2 0 0 5}$ & 50.002 \\
\hline $\mathbf{2 0 0 6}$ & 50.002 \\
\hline $\mathbf{2 0 0 7}$ & 50.002 \\
\hline
\end{tabular}

Table A. 2: Economic Utility of Bilateral Partnership with Iran to USSR/Russia (1985-2011). Economic utility is represented as the percentage value of Russian global exports that are derived from trade with Iran. Source: International Monetary Fund, "Direction of Trade Statistics" database.

\begin{tabular}{|llll|}
\hline Year & $\begin{array}{l}\text { \% Value of } \\
\text { USSR/Russian Global } \\
\text { Exports Derived from } \\
\text { Trade with Iran }\end{array}$ & Year & \% \\
\hline $\mathbf{1 9 8 5}$ & 0.238988172 & $\mathbf{1 9 9 8}$ & \\
$\mathbf{1 9 8 6}$ & 0.196697 & $\mathbf{1 9 9 9}$ & 0.696824 \\
$\mathbf{1 9 8 7}$ & 0.385178 & $\mathbf{2 0 0 0}$ & 0.613808 \\
$\mathbf{1 9 8 8}$ & 0.402469 & $\mathbf{2 0 0 1}$ & 1.08916 \\
$\mathbf{1 9 8 9}$ & 0.362264 & $\mathbf{2 0 0 2}$ & 0.715038 \\
$\mathbf{1 9 9 0}$ & 0.604494 & $\mathbf{2 0 0 3}$ & 1.00979 \\
$\mathbf{1 9 9 1}$ & 0.808358 & $\mathbf{2 0 0 4}$ & 1.151643 \\
$\mathbf{1 9 9 2}$ & 0.648988 & $\mathbf{2 0 0 5}$ & 0.816713 \\
$\mathbf{1 9 9 3}$ & 2.306168 & $\mathbf{2 0 0 6}$ & 0.656934 \\
$\mathbf{1 9 9 4}$ & 0.234419 & $\mathbf{2 0 0 7}$ & 0.847255 \\
$\mathbf{1 9 9 5}$ & 0.329113 & $\mathbf{2 0 0 8}$ & 0.727689 \\
$\mathbf{1 9 9 6}$ & 0.452622 & $\mathbf{2 0 0 9}$ & 1.178241 \\
$\mathbf{1 9 9 7}$ & 0.54927 & $\mathbf{2 0 1 0}$ & 1.045429 \\
& & $\mathbf{2 0 1 1}$ & 0.803921 \\
\hline
\end{tabular}


Table A. 3: Economic Utility of Bilateral Partnership with USSR/Russia to Iran (1988-2011). Economic utility is represented as the percentage value of Iranian global exports that are derived from trade with USSR/Russia. Source: International Monetary Fund, "Direction of Trade Statistics" database.

\begin{tabular}{|llll|}
\hline Year & $\begin{array}{l}\text { \% Value of Iranian } \\
\text { Global Exports Derived } \\
\text { from Trade with } \\
\text { USSR/Russia }\end{array}$ & Year & \% \\
\hline 1988 & 1.021415754 & $\mathbf{2 0 0 2}$ & 0.257071073 \\
\hline $\mathbf{1 9 8 9}$ & 0.193612486 & $\mathbf{2 0 0 3}$ & 0.218931901 \\
\hline 1990 & 0.641163732 & $\mathbf{2 0 0 4}$ & 0.307191663 \\
\hline 1991 & 1.773408229 & $\mathbf{2 0 0 5}$ & 0.287219678 \\
\hline 1992 & 0.800496503 & $\mathbf{2 0 0 6}$ & 0.345831759 \\
\hline 1993 & 0.223903959 & $\mathbf{2 0 0 7}$ & 0.431413911 \\
\hline 1994 & 0.403538977 & $\mathbf{2 0 0 8}$ & 0.371223429 \\
\hline 1995 & 0.323611999 & $\mathbf{2 0 0 9}$ & 0.317029513 \\
\hline 1996 & 0.253829503 & $\mathbf{2 0 1 0}$ & 0.304504634 \\
\hline 1997 & 1.40814131 & $\mathbf{2 0 1 1}$ & 0.290847088 \\
\hline 1998 & 0.94084998 & $\mathbf{2 0 0 3}$ & 0.257071073 \\
\hline 1999 & 0.534846668 & $\mathbf{2 0 0 4}$ & 0.218931901 \\
\hline $\mathbf{2 0 0 0}$ & 0.214507155 & $\mathbf{2 0 0 5}$ & 0.307191663 \\
\hline $\mathbf{2 0 0 1}$ & 0.158387038 & $\mathbf{2 0 0 6}$ & 0.287219678 \\
\hline
\end{tabular}


Table A. 4: Percentage Value of USSR/Russian Global Exports to Countries of the Global South (19812011). Source: International Monetary Fund, "Direction of Trade Statistics" database.

\begin{tabular}{|llll|}
\hline Year & $\begin{array}{l}\text { \% Value of Russian } \\
\text { Global Exports Destined } \\
\text { to Countries of the } \\
\text { Global South }\end{array}$ & Year & \% \\
\hline $\mathbf{1 9 8 1}$ & 42.768 & $\mathbf{1 9 9 6}$ & 41.717 \\
\hline $\mathbf{1 9 8 2}$ & 36.233 & $\mathbf{1 9 9 7}$ & 44.962 \\
\hline $\mathbf{1 9 8 3}$ & 37.595 & $\mathbf{1 9 9 8}$ & 44.772 \\
\hline $\mathbf{1 9 8 4}$ & 41.940 & $\mathbf{1 9 9 9}$ & 42.139 \\
\hline $\mathbf{1 9 8 5}$ & 40.099 & $\mathbf{2 0 0 0}$ & 39.979 \\
\hline $\mathbf{1 9 8 6}$ & 44.426 & $\mathbf{2 0 0 1}$ & 38.338 \\
\hline $\mathbf{1 9 8 7}$ & 40.961 & $\mathbf{2 0 0 2}$ & 41.436 \\
\hline $\mathbf{1 9 8 8}$ & 39.735 & $\mathbf{2 0 0 3}$ & 42.852 \\
\hline $\mathbf{1 9 8 9}$ & 38.767 & $\mathbf{2 0 0 4}$ & 39.282 \\
\hline $\mathbf{1 9 9 0}$ & 37.071 & $\mathbf{2 0 0 5}$ & 40.321 \\
\hline $\mathbf{1 9 9 1}$ & 34.761 & $\mathbf{2 0 0 6}$ & 38.737 \\
\hline $\mathbf{1 9 9 2}$ & 37.242 & $\mathbf{2 0 0 7}$ & 42.211 \\
\hline $\mathbf{1 9 9 3}$ & 30.694 & $\mathbf{2 0 0 8}$ & 42.989 \\
\hline $\mathbf{1 9 9 4}$ & 40.674 & $\mathbf{2 0 0 9}$ & 41.082 \\
\hline $\mathbf{1 9 9 5}$ & 42.364 & $\mathbf{2 0 1 0}$ & 37.368 \\
\hline & & $\mathbf{2 0 1 1}$ & 41.363 \\
\hline
\end{tabular}


Table A. 5: Media Articles Describing Russian-Iranian Relations (1979-2011). Source: Lexis Nexus; articles derived from search of 'Major World Publications' using search terms [HEADLINE (Russia and Iran) AND relations].

\begin{tabular}{|llll|}
\hline Year & $\begin{array}{l}\text { Number of Media } \\
\text { Articles Describing } \\
\text { Russian-Iranian } \\
\text { Relations }\end{array}$ & Year & \\
\hline $\mathbf{1 9 7 9}$ & 15 & $\mathbf{1 9 9 6}$ & 45 \\
\hline $\mathbf{1 9 8 0}$ & 18 & $\mathbf{1 9 9 7}$ & 53 \\
\hline $\mathbf{1 9 8 1}$ & 3 & $\mathbf{1 9 9 8}$ & 96 \\
\hline $\mathbf{1 9 8 2}$ & 18 & $\mathbf{1 9 9 9}$ & 93 \\
\hline $\mathbf{1 9 8 3}$ & 5 & $\mathbf{2 0 0 0}$ & 107 \\
\hline $\mathbf{1 9 8 4}$ & 8 & $\mathbf{2 0 0 1}$ & 246 \\
\hline $\mathbf{1 9 8 5}$ & 8 & $\mathbf{2 0 0 2}$ & 239 \\
\hline $\mathbf{1 9 8 6}$ & 10 & $\mathbf{2 0 0 3}$ & 146 \\
\hline $\mathbf{1 9 8 7}$ & 17 & $\mathbf{2 0 0 4}$ & 104 \\
\hline $\mathbf{1 9 8 8}$ & 10 & $\mathbf{2 0 0 5}$ & 165 \\
\hline $\mathbf{1 9 8 9}$ & 29 & $\mathbf{2 0 0 6}$ & 401 \\
\hline $\mathbf{1 9 9 0}$ & 17 & $\mathbf{2 0 0 7}$ & 177 \\
\hline $\mathbf{1 9 9 1}$ & 16 & $\mathbf{2 0 0 8}$ & 169 \\
\hline $\mathbf{1 9 9 2}$ & 15 & $\mathbf{2 0 0 9}$ & 231 \\
\hline $\mathbf{1 9 9 3}$ & 3 & $\mathbf{2 0 1 0}$ & 294 \\
\hline $\mathbf{1 9 9 4}$ & 12 & $\mathbf{2 0 1 1}$ & 167 \\
\hline $\mathbf{1 9 9 5}$ & 94 & & \\
\hline & & & \\
\hline
\end{tabular}


Table A. 6: Similarity of Russian-Iranian Security Alliance Portfolios (1966-2000). Source: EUGene version 3.204; Bennett and Stam (2000); Signorino \& Ritter (1998). EUGene calculates the $S$ statistic on the basis of a weighted, regional measure of similarity using data derived from the following Correlates of War data sets: "Formal Alliances" (Gibler \& Sarkees, 2004; Gibler, 2009; Singer \& Small, 1966; Small \& Singer, 1969); and "National Material Capabilities" (Singer, Bremmer, \& Stuckey, 1972; Singer, 1987) datasets.

\begin{tabular}{|lllr|}
\hline Year & $\begin{array}{l}\text { S-coefficient for } \\
\text { Similarity of } \\
\text { Security Alliance } \\
\text { Portfolios }\end{array}$ & Year & S-coefficient \\
\hline 1966 & -0.001711 & 1983 & 0.174967 \\
\hline 1967 & -0.003498 & 1984 & 0.177931 \\
\hline 1968 & -0.014991 & 1985 & 0.165975 \\
\hline 1969 & -0.017957 & 1986 & 0.175111 \\
\hline 1970 & -0.031966 & 1987 & 0.17906 \\
\hline 1971 & -0.048841 & 1988 & 0.181775 \\
\hline 1972 & -0.052667 & 1989 & 0.302991 \\
\hline 1973 & -0.043322 & 1990 & -0.29645 \\
\hline 1974 & -0.050521 & 1991 & -0.33349 \\
\hline 1975 & -0.078951 & 1992 & 0.561958 \\
\hline 1976 & -0.077203 & 1993 & 0.599405 \\
\hline 1977 & -0.063871 & 1994 & 0.548558 \\
\hline 1978 & -0.055053 & 1995 & 0.55328 \\
\hline 1979 & -0.038507 & 1996 & 0.570579 \\
\hline 1980 & 0.204075 & 1997 & 0.580171 \\
\hline 1981 & 0.204674 & 1998 & 0.606536 \\
\hline 1982 & 0.173759 & 1999 & 0.605353 \\
\hline & & $\mathbf{2 0 0 0}$ & 0.348362 \\
\hline & & & \\
\hline
\end{tabular}


Table A. 7: Annual scores for sub-components of General Political Affinity and 5 year period averages utilized in Chapter II.

\begin{tabular}{|c|c|c|c|c|c|}
\hline 1987-91 & 1987 & 1988 & 1989 & 1990 & 1991 \\
\hline Trade in Conventional Weapons & 2 & 2 & 7 & 6 & 7 \\
\hline Nuclear Development & 1 & 1 & 4 & 4 & 4 \\
\hline Caspian Sea Delimitation & 6 & 6 & 6 & 6 & 6 \\
\hline General Political Affinity Score & 9 & 9 & 17 & 16 & 17 \\
\hline Period Average 87-91 & 13.6 & & & & \\
\hline 1992-96 & 1992 & 1993 & 1994 & 1995 & 1996 \\
\hline Trade in Conventional Weapons & 2 & 7 & 5 & 6 & 6 \\
\hline Nuclear Development & 5 & 3 & 5 & 3.625 & 4.5 \\
\hline Caspian Sea Delimitation & 6 & 6 & 6 & 6 & 7 \\
\hline General Political Affinity Score & 13 & 16 & 16 & 15.625 & 17.5 \\
\hline Period Average 92-96 & 15.625 & & & & \\
\hline 1997-01 & 1997 & 1998 & 1999 & 2000 & 2001 \\
\hline Trade in Conventional Weapons & 6 & 7 & 7 & 7 & 7 \\
\hline Nuclear Development & 4.5 & 4.5 & 5.75 & 5.125 & 3.5 \\
\hline Caspian Sea Delimitation & 7 & 2 & 2 & 2 & 2 \\
\hline General Political Affinity Score & 17.5 & 13.5 & 14.75 & 14.125 & 12.5 \\
\hline Period Average 97-01 & 14.475 & & & & \\
\hline 2002-06 & 2002 & 2003 & 2004 & 2005 & 2006 \\
\hline Trade in Conventional Weapons & 7 & 7 & 4 & 6 & 7 \\
\hline Nuclear Development & 3.5 & 2.75 & 3 & 4.1 & 3.6 \\
\hline Caspian Sea Delimitation & 2 & 2 & 2 & 2 & 2 \\
\hline General Political Affinity Score & 12.5 & 11.75 & 9 & 12.1 & 12.6 \\
\hline Period Average 02-06 & 11.59 & & & & \\
\hline 2007-11 & 2007 & 2008 & 2009 & 2010 & 2011 \\
\hline Trade in Conventional Weapons & 6 & 4 & 4 & 1 & 1 \\
\hline Nuclear Develo pment & 2.75 & 2.75 & 2.75 & 2.75 & 3.8 \\
\hline Caspian Sea Delimitation & 2 & 2 & 2 & 2 & 2 \\
\hline General Political Affinity $S$ core & 10.75 & 8.75 & 8.75 & 5.75 & 6.8 \\
\hline Period Average 0 7-11 & 8.16 & & & & \\
\hline
\end{tabular}

